\title{
The effect of long-term regional pumping on hydrochemistry and dissolved gas content in an undeveloped shale-gas-bearing aquifer in southwestern Ontario, Canada
}

\author{
Stewart M. Hamilton • Stephen E. Grasby • \\ Jennifer C. McIntosh • Stephen G. Osborn
}

\begin{abstract}
Baseline groundwater geochemical mapping of inorganic and isotopic parameters across $44,000 \mathrm{~km}^{2}$ of southwestern Ontario (Canada) has delineated a discreet zone of natural gas in the bedrock aquifer coincident with an $8,000-\mathrm{km}^{2}$ exposure of Middle Devonian shale. This study describes the ambient geochemical conditions in these shales in the context of other strata, including Ordovician shales, and discusses shale-related natural and anthropogenic processes contributing to hydrogeochemical conditions in the aquifer. The three Devonian shales - the Kettle Point Formation (Antrim equivalent), Hamilton Group and Marcellus Formation-have higher DOC, DIC, $\mathrm{HCO}_{3}$, $\mathrm{CO}_{2(\mathrm{aq})}, \mathrm{pH}$ and iodide, and much higher $\mathrm{CH}_{4(\mathrm{aq}) \text {. The two }}$ Ordovician shales - the Queenston and Georgian-Bay/Blue Mountain Formations - are higher in $\mathrm{Ca}, \mathrm{Mg}, \mathrm{SO}_{4}$ and $\mathrm{H}_{2} \mathrm{~S}$. In the Devonian shale region, isotopic zones of Pleistoceneaged groundwater have halved in size since first identified in the 1980s; potentiometric data implicate regional groundwater extraction in the shrinkage. Isotopically younger waters invading the aquifer show rapid increases in $\mathrm{CH}_{4(\mathrm{aq})}, \mathrm{pH}$ and iodide with depth and rapid decrease in
\end{abstract}

Received: 23 July 2014 / Accepted: 30 December 2014

Published online: 3 February 2015

(C) The Author(s) 2015. This article is published with open access at Springerlink.com

S. M. Hamilton (৫)

Ontario Geological Survey, 933 Ramsey Lake Road, Sudbury, ON P3E 2G9, Canada

e-mail: stew.hamilton@ontario.ca

Tel.: 705-670-5915

S. E. Grasby

Geological Survey of Canada, Calgary, AB T2L 2A7, Canada

J. C. McIntosh

Hydrology and Water Resources,

University of Arizona, Tucson, AZ 85721, USA

J. C. McIntosh

United States Geological Survey, Tucson, AZ 85721, USA

Present Address:

S. G. Osborn

Geology,

California State Polytechnic University, Pomona, CA, USA oxidized carbon species including $\mathrm{CO}_{2}, \mathrm{HCO}_{3}$ and DIC, suggesting contemporary methanogenesis. Pumping in the Devonian shale contact aquifer may stimulate methanogenesis by lowering TDS, removing products and replacing reactants, including bicarbonate, derived from overlying glacial sedimentary aquifers.

Keywords Hydrochemistry · Shale gas · Water supply $\cdot$ Methane $\cdot$ Canada

\section{Introduction}

A groundwater geochemical mapping project by the Ontario Geological Survey (OGS) has been completed in a $44,000 \mathrm{~km}^{2}$ area of southwestern Ontario, Canada. The project is part of the larger ongoing Ambient Groundwater Geochemistry program, the purpose of which is to characterize the current state of groundwater quality in accessible parts of the province at a regular sample density to a high degree of analytical completeness. The geochemical data, which include dissolved gas concentrations, have delineated an area of elevated natural gas $\left(\mathrm{CH}_{4}\right)$ in groundwater that is coincident with the subcrop of Devonian-aged shale formations in southwestern Ontario. The gas occurrence is near ubiquitous in shale bedrock-derived waters in this area and very common in water derived from wells in overburden that overlies the shales. Sporadic gas occurrences were also noted that spatially relate to Devonian carbonates and Ordovician shale units. There has never been commercial shale gas extraction in Ontario and the occurrence of methane gas in Devonian shales has long been recognized as a natural phenomenon (Caley 1943).

The impact of shale gas development on shallow potable groundwater resources is of rising international concern. Concerns include migration of natural gas, hydraulic fracturing fluids, and/or brines into shallow aquifers (Kargbo et al. 2010; Osborn et al. 2011; Jackson et al. 2013). Research had been hindered, however, by the lack of baseline analyses of natural groundwater conditions in regions of significant shale gas potential and in areas of current shale gas development (Vidic et al. 2013). 
The purpose of this report is to present the results of an investigation into the groundwater geochemical and flow conditions in and around the Devonian shales to provide baseline data in gas-yielding shale formations in general that have not been impacted by commercial development, and to understand the hydrogeochemical processes operating in the organic-rich shales of southwestern Ontario.

Major ion chemistry, selected trace elements, dissolved gases, and stable and radioactive isotopes of water were collected for 1010 samples from domestic, farm, and monitoring wells completed in glacial overburden units and 14 major bedrock units ranging from Ordovician to middle Devonian in age (Hamilton 2015). These strata include five gas-yielding shale units (Armstrong and Carter 2010), treated here in four groups: (1) the Devonian Kettle Point Formation, (2) Hamilton Group, (3) Marcellus Formation, and (4) the Ordovician Queenston and underlying Georgian Bay-Blue Mountain formations. The Devonian shales are treated in greater detail in this report because of their spatial association with significant methane accumulations (Hamilton 2015; McIntosh et al. 2014) and with decadal changes in regional water levels. Another paper related to this work (McIntosh et al. 2014) discusses the spatial distribution of gas, isotopic and chemical composition of the gas, and mechanisms and timing of gas formation in Paleozoic bedrock and overburden deposits, and its relationship to water chemistry.

\section{Background}

\section{Study area}

The detailed study area encompasses all of the on-land exposure of Devonian shale in southwestern Ontario (Fig. 1). The broader study area encompasses all of southwestern Ontario and is intended to provide context for the geochemical, hydrogeological and isotopic investigation of the shale region. Data were derived from the 2007-2014 Ambient Groundwater database, which can be downloaded without charge from the website of the Ontario Ministry of Northern Development and Mines (Hamilton 2015). The database allows detailed investigation of the effect of host lithology on water chemistry, which is profound (Mellor 2008 and the following section 'Major ion and trace element geochemistry'). It has also revealed additional processes that affect water chemistry including karst influence on the flow path and residence time resulting from an extensive, previously unreported breathing-well zone (Freckelton 2013).

For the sake of geological and hydrogeological completeness, 50 samples were borrowed from the 2011 study area and serve to infill a small part of southwestern Ontario (Fig. 1) that had been excluded from the 2007 to 2010 work. The 2011 study (Hamilton et al. 2011) used the same sampling and analytical protocols as previous years (Hamilton et al. 2007; Hamilton and Brauneder 2008).

Hydrogeology Journal (2015) 23: 719-739
Land use in southwestern Ontario is predominantly agricultural with some forested terrain. In all, $97 \%$ of the samples in this study were collected from rural areas. Two samples were taken in each $10 \times 10 \mathrm{~km}$ block, which allowed latitude to avoid obvious sources of contamination such as quarries or landfills. Road salt, and farmbased contaminants such as pesticides and fertilizers may have affected bedrock well chemistry but, as of yet, little evidence of this is apparent in the bedrock-well component of the database, the chemistry of which is largely controlled by host lithology (Mellor 2008).

Southwestern Ontario has a temperate climate with warm summers and mild winters and average daily highs in the coldest/warmest months (January/July) of -5.6 and $20.6^{\circ} \mathrm{C}$, respectively (Canada Climate Normals 2014). Precipitation ranges from 800 to $1000 \mathrm{~mm} /$ year across the region, including 100 to $300 \mathrm{~cm}$ of snowfall, while evapotranspiration varies from 500 to $600 \mathrm{~mm} / \mathrm{year}$ (Ontario Ministry of Natural Resources 1984).

\section{Bedrock geology}

Southern Ontario is underlain by the Michigan and Appalachian Paleozoic sedimentary basins, which are separated by the Algonquin and Findlay arches (Fig. 1; Sanford et al. 1985). The two arches are separated by the Chatham Sag, an area of flat lying Paleozoic sedimentary strata. This sedimentary succession is bounded by the Canadian Shield to the north and northeast. Within the carbonate dominated Paleozoic succession, the Devonian organic rich shale units are the focus of this study (Kettle Point, Hamilton and Marcellus shale units). While these shale units have inherently low permeability, natural fracture systems in the shales support viable potable groundwater supplies (Singer et al. 2003).

As a result of extensive Quaternary sedimentary cover, there is very little outcrop exposure of the Devonian shales in southwestern Ontario. The bedrock mapping in the area relied heavily on borehole records and is partly based on earlier mapping by the Ontario Geological Survey that is over 30 years old. Therefore, limited remapping of the shale boundaries and thickness was carried out as part of this study as described in the methods section.

\section{Devonian shale}

The Kettle Point, Hamilton and Marcellus shale units are more extensive than had been originally mapped (Fig. 2). Most of the boundary changes occur in areas where the shale is thin and occasionally discontinuous. However, this study shows that even where the water-hosting shale is thin, it appears to be important in controlling the chemistry of groundwater. The four Devonian shale units described below have a combined average on-shore thickness of $107 \mathrm{~m}$ (Table 1) and a maximum on-shore depth of $255 \mathrm{~m}$ from ground surface. The revised boundaries are more consistent with the chemical and physical observations on water from a number of wells 


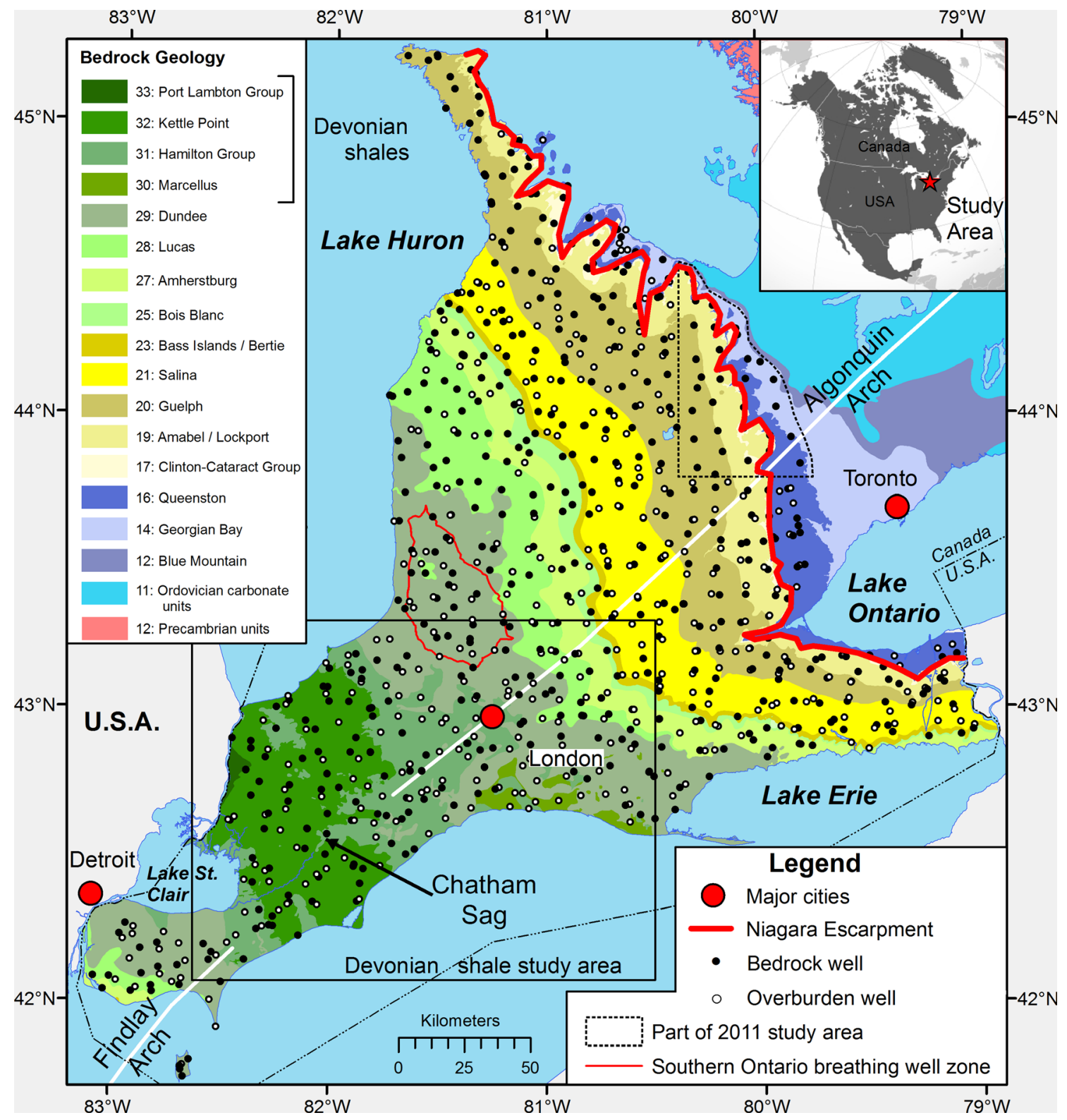

Fig. 1 Locations of wells sampled as part of the Ambient Groundwater Geochemistry Program of the Ontario Geological Survey, in relation to bedrock geology. The detailed study area (Fig. 2) is also indicated. The Niagara Peninsula is in the southeast of this map and bounded by the Niagara River (border), in the east, and lakes Erie and Ontario. Green units are Devonian in age, yellow are Silurian and blue Ordovician. All units are formations unless otherwise stated. See text for a description of lithology and structure. Geology is modified after Armstrong and Dodge (2007)

(Fig. 2). In particular, they account for the presence of significant gas and other shale-related geochemical parameters, discussed in the following, that are observed in wells finished in what had been previously mapped as Dundee Formation carbonates.

The Upper Devonian Port Lambton Group shales comprise the youngest and least exposed unit in the study area (Figs. 1 and 2) and no groundwater samples collected as part of this project are associated with it. The underlying Upper Devonian Kettle Point Formation comprising dark brown to black non-calcareous shale with pyrite nodules, subcrops between Lake Erie and Lake Huron in the Chatham Sag region (Fig. 1). The shale is organic-rich with 3.6-15.0\% total organic carbon (TOC) and is age-equivalent to the Antrim Shale in the Michigan Basin (Obermajer et al. 1997). It has a maximum observed on-land thickness of $109 \mathrm{~m}$, and overlies the Middle Devonian Hamilton Group. The Kettle Point Formation is covered by glacial sediments for almost all of its extent.

The Hamilton Group comprises mudstones and marginally mature shales with thin carbonate layers. In Ontario, the lowest unit in the Hamilton Group is the Bell Formation, a blue-grey calcareous shale that is underlain by the Marcellus Formation. In the United States, the Marcellus Formation is considered to be part of the Hamilton Group (Armstrong and Carter 2010). 


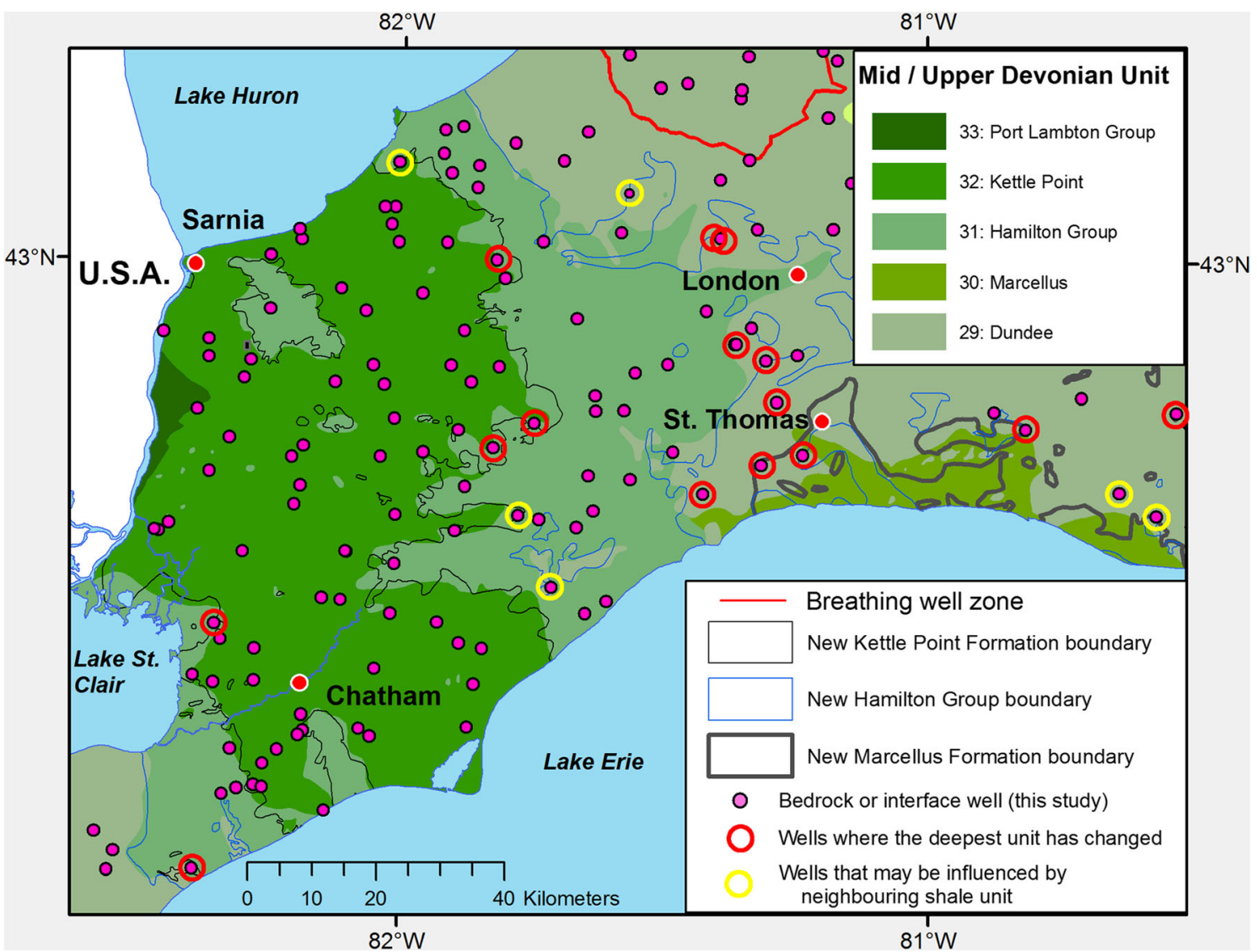

Fig. 2 Detailed Devonian shale study area. New mapped boundaries of the Devonian shale units and Dundee Formation carbonates and the affected Ambient Groundwater stations are shown. Colored units represent the original mapped boundaries (Armstrong and Dodge 2007); colored lines show the new boundaries. Changes were based on the existing map compilation and more current well and borehole records (MNR 2013; MOE 2013)

Where it is of sufficient thickness to identify, the Marcellus Shale is mapped as a separate unit beneath Quaternary glacial sedimentary deposits along the northern shore of Lake Erie and extending beneath the central portion of the Lake. In Ontario, the Marcellus Formation shale is never more than a few meters thick on land but is up to $12 \mathrm{~m}$ thick under Lake Erie (Armstrong and Carter 2010). It contains up to $13.5 \%$ TOC, and is marginally immature to mature (Obermajer et al. 1997). Where the Hamilton Group is present on-land, the extent to which the Marcellus Formation underlies it has not been quantified due to its thin and discontinuous nature.

Near the northeast extent of the Hamilton Group exposure is a bedrock escarpment that defines the western boundary of a buried bedrock valley known as the

Table 1 Devonian shale thickness and extents

\begin{tabular}{lccccc}
\hline Shale unit & \multicolumn{2}{l}{$\begin{array}{l}\text { On-land } \\
\text { thickness }(\mathrm{m})\end{array}$} & & \multicolumn{2}{l}{ Surface area $\left(\mathrm{km}^{2}\right)$} \\
\cline { 2 - 3 } \cline { 6 - 6 } \cline { 5 - 6 } & Avg. & Max. & & On-land & Offshore \\
\hline Port Lampton Group & 24.2 & 71.2 & & 80 & - \\
Kettle Point Formation & 27.8 & 109.3 & & 4,311 & 4,412 \\
Hamilton Group & 54.7 & 131.2 & & 7,790 & 7,869 \\
Marcellus Formation & $\sim 2$ & $<10$ & & 511 & 4,151 \\
All Devonian shale & 107 & $<255$ & & 8,192 & 8,000 \\
\hline
\end{tabular}

Hydrogeology Journal (2015) 23: 719-739
Ipperwash Trough (Karrow 1973). The escarpment is buried along almost all of its extent and it controls the exposure and thickness of the shale units. The Kettle Point shale is exposed to the west and thins out completely within several kilometers east of the escarpment, whereas the Hamilton Group thins appreciably east of the escarpment from a typical 70-90 m thickness to typically less than $25 \mathrm{~m}$ in the trough.

\section{Devonian carbonate strata}

Most of the following description of the Middle and Lower Devonian carbonate units that underlie the shales was taken from Armstrong and Carter (2010) unless otherwise stated. The Dundee Formation limestone (Fig. 1) underlies the basal Hamilton Group disconformably or, where present, the Marcellus Formation conformably and sharply. It comprises up to $45 \mathrm{~m}$ of medium to thickly bedded, commonly bituminous limestone with abundant chert nodules and minor dolostone. In the deeper subsurface, the unit hosts significant economic oil accumulations and minor gas shows.

The Dundee Formation unconformably overlies the Lucas Formation, which is a high purity limestone in the 
southern parts of its exposure in Ontario and a dolostone in other areas. The Lucas Formation is up to $96 \mathrm{~m}$ thick in the western part of southwestern Ontario but pinches out entirely between the Dundee and Amherstburg (Onondaga) formations in the south-central part of the region (Fig. 1). Anhydrite and gypsum beds and breccias apparently associated with evaporite dissolution are reported in the subsurface. Locally, celestite and fluorite comprise a significant volume of the rock. Many of the wells sampled as part of the Ambient Groundwater Geochemistry program were completed in the Lucas Formation breccias, which have high transmissivities (Waterloo Hydrogeologic Incorporated, 2007. Six Conservation Authorities FEFLOW Groundwater Modelling Project. Unpublished report prepared for the Upper Thames Conservation Authority, Waterloo, Ontario, 60 pp.)

The Lucas Formation in southwest Ontario also has perhaps the largest breathing-well zone ever reported (Fig. 1; Freckelton 2013); a contiguous area that affects thousands of domestic wells and encompasses approximately $1,400 \mathrm{~km}^{2}$. Intake or exhalation periods during atmospheric pressure-related breathing events can last for more than a week and measured exhalation volumes from some wells exceed $3 \mathrm{~m}^{3} / \mathrm{min}$ (Freckelton 2013), indicating that an enormous volume of unsaturated void-space exists in this part of the Lucas Formation. The void-space phenomenon continues eastward to Lake Huron (Freckelton 2013) and perhaps northward from the breathing-well zone but in these areas the Lucas Formation is fully saturated. The Lucas Formation is reported to contain karstic features and porosity in both the surface and subsurface (Brunton and Dodge 2008; Armstrong and Carter 2010).

The Amherstburg Formation comprises bituminous, cherty limestone and dolostone and is up to $60 \mathrm{~m}$ thick in Ontario. It is fossiliferous and commonly biohermal and is equivalent to the Onondaga cherty limestone found in the eastern part of southwestern Ontario and in New York State. In this report, the two formations are considered equivalent (Fig. 1). The Bois Blanc Formation underlies the Amherstburg Formation and has a gradational and possibly conformable contact (Armstrong and Carter 2010), and disconformably overlies Silurian strata. It is a cherty, argillaceous, medium-bedded limestone that is up to $50 \mathrm{~m}$ thick.

\section{Silurian and Ordovician strata}

The Upper Silurian Bass Island/Bertie Formation comprises cherty dolostone with some minor gypsum, celestite, pyrite, and bituminous layers. The underlying Silurian Salina Formation is composed of evaporites, evaporitic carbonates, and shales. The underlying Silurian Guelph, Amabel, and Lockport formations are primarily comprised of dolostone with some disseminated pyrite. The Clinton-Cataract Group, at the base of the Silurian succession, is composed of sandstone, shale with calcareous sandstone, dolostone, and limestone (Armstrong and Carter 2006).

The Upper Ordovician Queenston Formation is composed of mixed terrigenous and carbonate sediments, primarily red silty shales that locally contain gypsum, alternating with thin grey shales, calcareous siltstone and sandstone, and limestone (Brogly et al. 1998). Shales in the Queenston Formation are thermally immature with average TOC contents of $0.11 \%$ (INTERA Engineering Ltd 2011). There is only a small subcropping of the underlying Upper Ordovician Georgian Bay and Collingwood-Blue Mountain formations in the study area, along the southern shore of Lake Huron near the Georgian Bay (Fig. 1). The Collingwood and Blue Mountain formations are age-equivalent to the Utica Shale in New York State and Quebec. The Georgian Bay Formation is composed of thermally immature to mature grey shale (average TOC of $0.25 \%$; INTERA Engineering Ltd 2011) and bioclastic-rich limestone beds, while the Collingwood-Blue Mountain Formation contains grey to black thermally mature shale with pyrite nodules, and TOC values from 0.90 to $11 \%$ (Obermajer et al. 1998; Hamblin 2006; INTERA Engineering Ltd 2011). The deeper, more organic-rich part of the Collingwood-Blue Mountain Formation subcrops east of the study area and it is unlikely that any of the groundwater samples discussed here were hosted in it.

\section{Surficial geology}

Quaternary-aged glacial sedimentary deposits that can exceed $100 \mathrm{~m}$ in thickness overlie the Paleozoic bedrock surface throughout the southwestern Ontario study area. The region experienced multiple glacial episodes during the Pleistocene that deposited thick glacial drift materials including till, ice-contact stratified drift and glaciolacustrine sediments. Near the lakes, glaciolacustrine clays dominate the glacial sedimentary strata and contain a high proportion of silt-sized carbonate material (Barnett et al. 1991). In southwestern Ontario, a large number of buried valleys, troughs and escarpments exist in the bedrock surface beneath glacial sediments, many of which were part of pre-glacial drainage systems. Glacial drift thickness in the central part of the Devonian shale area, west of the Ipperwash Escarpment, is approximately 10-30 $\mathrm{m}$. In the Ipperwash Trough, a few kilometers east of the escarpment, drift thickness increases to $50-80 \mathrm{~m}$ (Gao et al. 2006). Most of the glacial materials filling the trough are fine-grained till and glaciolacustrine clays that are collectively referred to in drill records as "clay". Clay deposits consistently exceeding $20 \mathrm{~m}$ in thickness are also reported along the north shore of Lake Erie, the east and south shores of Lake St. Clair and to approximately $10 \mathrm{~km}$ east from the St. Clair River.

\section{Regional hydrogeology}

Singer et al. (2003) showed that southern Ontario is generally characterized by a potentiometric surface that 
parallels regional topography. Bedrock wells and many deeper overburden wells in southwestern Ontario are most often completed in a hydraulically conductive zone near the interface between bedrock and glacial overburden (Weaver et al. 1995) that is often referred to as the interface or 'contact' aquifer. Groundwaters hosted in the contact aquifer generally exhibit the chemical character of bedrock and the bedrock-derived basal till (Singer et al. 2003) in both dissolved solid (Hamilton 2015) and dissolved gas (McIntosh et al. 2014) content.

All bedrock units have some localized capacity to produce groundwater for domestic wells; however, average transmissivity values (Singer et al. 2003) for the Devonian and Silurian carbonate units $\left(27.1-40.4 \mathrm{~m}^{2} / \mathrm{s}\right)$ are considerably higher than the Devonian shales (5.3$\left.8.6 \mathrm{~m}^{2} / \mathrm{s}\right)$.

Modern recharge occurs across the study area, but previous work has shown impacts of glacial meltwater recharge on aquifer systems in southern Ontario. Desaulniers et al. (1981) show $\delta^{18} \mathrm{O}$ values of porewaters of glacial tills shift from -9 to $-10 \%$, at the water table, down to -14 to $-17 \%$ where the sample depth is greater than $20 \mathrm{~m}$ or where ${ }^{14} \mathrm{C}$ ages of the waters are $>8,000$ years BP. Husain et al. (2004) reported similar trends in pore waters of glacial till and interpreted values of -16 to $-17.5 \%$ to represent glacial recharge. Aravena et al. (1995) also report the presence of glacial meltwater in surficial sediments. McNutt et al. (1987) and Weaver et al. (1995) show that deeper saline formation waters in bedrock units have distinct stable isotope trends consistent with basinal brines, some bedrock aquifers show evidence of mixing with glacial meltwaters (Dollar 1988; McNutt et al. 1987; Dollar et al. 1991; Aravena et al. 1995; Husain 1996). Weaver et al. (1995) also show direct evidence for glaciation affecting bulk hydraulic conductivity of bedrock in southern Ontario and vertical migration of glacial waters associated with glacial-induced fracture flow. While these localized studies show evidence for glacial melt waters in southern Ontario aquifer systems, the regional extent is uncertain.

Husain (1996) and Husain et al. (2004) used Ministry of Environment (MOE) well records to show that, when bedrock wells were first drilled in the Devonian shale area in the 1940s, water levels generally followed topography. As wells were drilled and pumped over the following decades, static water levels after drilling showed a steady regional drop until the 1970s and then a partial rise by the 1980s in western areas near Lake St. Clair and Sarnia. This reversal was due to the widespread installation of rural pipelines to replace poor quality and low quantity domestic groundwater supplies. The rapid drawdown was attributed to the thin nature of the bedrock interface aquifer, beneath the thick clay aquitard (Husain 1996; Husain et al. 2004), that had adequate transmissivity for individual water supplies but low overall aquifer storage. Husain et al. (2004) argued that water withdrawn by the several thousand domestic wells in the region could have been supplied from storage in the overlying aquitard and/ or lateral flow. They used 2D finite difference modeling to estimate that removal from storage could have provided all the water withdrawn and that natural horizontal groundwater velocities are extremely low.

Despite regional drawdown of water levels, Husain (1996) and Husain et al. (2004) noted the persistence of Pleistocene-aged waters in a number of areas in southwestern Ontario. Husain (1996) argued that, due to reduced water usage and pipeline construction, the Pleistocene zones may continue for millennia (Husain et al. 2004) until eventually eradicated by diffusion through the aquitard from the weathered zone.

\section{Methods}

For the purposes of this study, the more recently available drill records from the Ministry of Environment Water Well Record Database (MOE 2013) and the Ministry of Natural Resources Petroleum Well Data (MNR 2013) were examined and more precise boundaries for the major shale units were established. Approximately 81,000 water well records encompassing the Devonian share area were queried and, after filtering to remove bad locations, the first bedrock encountered in each well was plotted as color-coded dots in the ArcMap ${ }^{\circledR}$ geographic information system. This methodology was very successful in delineating the various contacts because of the very large number of stations and the color contrast between the Kettle-Point (brown-black), Hamilton Group (blue-grey) and Marcellus Formation (black); and the contrasting lithology of the shales and the Dundee Formation carbonates.

In addition, the elevations of the top and bottom of shale surfaces were determined, as were unit thicknesses using approximately 26,000 oil and gas well lithology 'picks' from the MNR database. In this case, the database was again filtered to remove bad elevations, etc. and the top and bottom elevations of each unit were plotted using kriging in ArcMap ${ }^{\circledR}$ and trimmed using the maximum extents determined in the earlier water-well exercise. The thicknesses were then determined by subtracting the various lithological surfaces one from another using the ArcMap Spatial Analyst ${ }^{\circledR}$ feature. The results are shown in Table 1. Unless otherwise stated, the thickness, depth and area statistics described for the shale in the 'Bedrock geology' section were derived from this work. All area statistics, including under-lake exposures, are for Canadian exposures only.

Groundwater samples were collected predominantly from water supply wells in Paleozoic bedrock and overburden formations (Fig. 1) from 2007 to 2010 as part of the Ambient Groundwater Geochemistry program of the Ontario Geological Survey (Hamilton 2015). The pH, temperature, dissolved oxygen, oxidation-reduction potential, $\mathrm{H}_{2} \mathrm{~S}$ and alkalinity of water samples were measured in the field. Alkalinity was determined by titration using a $\mathrm{HACH}$ 16900-01 digital titrator. Bicarbonate, as $\mathrm{HCO}_{3}{ }^{-}$, was obtained by a direct linear conversion from alkalinity, as $\mathrm{CaCO}_{3}$. Fifteen samples in 2007 required bicarbonate 
determination by charge balance owing to incorrect field titration, which amounts to $1.5 \%$ of the bicarbonate data reported (Hamilton 2015). Hydrogen sulfide was determined in the field using the methylene-blue method with a HACH model 2238-01 test kit (0.01 ppm lower detection limit). Dissolved $\mathrm{CH}_{4}$ and $\mathrm{CO}_{2}$ were also measured and the methods, results and implications of the $\mathrm{CH}_{4}$ distribution are discussed in detail in McIntosh et al. (2014).

Of the available 1010 samples, 596 are used in this study and these were collected from wells finished in bedrock, or at the bedrock/overburden interface (Fig. 1), and have complete or near complete chemical analyses including stable isotopes. The overburden stable isotope data are used for comparison with the bedrock data but otherwise overburden data are not discussed here in detail. Repeat samples and samples with only a partial suite of analytical parameters are also excluded.

Major ion chemistry, including $\mathrm{Ca}, \mathrm{Mg}, \mathrm{K}, \mathrm{Na}, \mathrm{Fe}$, $\mathrm{SO}_{4}$, and $\mathrm{Cl}$ were measured at the Ontario Geological Survey Geoscience Laboratories (Geolabs) by inductively coupled plasma optical emissions and mass spectrometry, and ion chromatography. Dissolved organic carbon (DOC) was measured in 2007 at Caduceon Environmental Laboratories in Windsor, Ontario using UV Persulphate oxidation (EPA Method 415.1), and in 2008, 2009 and 2010 at SGS Analytical Laboratories in Lakefield, Ontario on a Skalar ${ }^{\circledR}$ Autoanalyzer (from SM 5310C Standard Methods). Charge balance error for the major ions was $\leq 10 \%$ for $97 \%$ of samples and $\leq 5 \%$ for $87 \%$ of the samples. The charge imbalance for the $3 \%$ of samples that showed an error of greater than $10 \%$ is unlikely to result from analytical error because the redundant analytical datasets confirm the major ion compositions. The error may be a result of sample collection from a continuous water stream and slight composition differences between the cation, anion and/or bicarbonate samples.

In the statistics described in the 'Results' section, 50 samples from a contiguous area in the Niagara peninsula were excluded from the dataset because, unlike the rest of southwestern Ontario, the anomalously high major and trace element concentrations in bedrock groundwater in this area are specific to the region and not the geological unit. Several possible causes for this have been advanced including anthropogenic influence (Matheson 2011).

Water samples were analyzed for oxygen and hydrogen stable isotopes in 2007-2009 at the Geological Survey of Canada, Quebec. Oxygen isotopes were measured on $\mathrm{CO}_{2}$ isotopically equilibrated with $\mathrm{H}_{2} \mathrm{O}$, and $\delta \mathrm{D}$ was measured on $\mathrm{H}_{2}$ equilibrated with $\mathrm{H}_{2} \mathrm{O}$ with a platinum catalyst (Horita and Kendall 2004). Precision was $\pm 0.2 \%$ for $\delta^{18} \mathrm{O}$ and $\pm 1 \%$ for $\delta D$. Samples from 2010 were analyzed at the University of Western Ontario Laboratory for Stable Isotope Science using a Picarro ${ }^{\circledR}$ L1102-I $\delta^{2} \mathrm{H}$ and $\delta^{18} \mathrm{O}$ Water Isotope Analyzer with a reported precision and accuracy of better than $\pm 0.2 \%$ for $\delta^{18} \mathrm{O}$ and $\pm 2.5 \%$ for $\delta \mathrm{D}$. The small group of samples (50) from the 2011 study area was analyzed by Isotope Tracer Technologies in Waterloo, Ontario using a Picarro ${ }^{\circledR}$ L2120-I Isotopic
Water Analyzer with a precision and accuracy of \pm 0.2 for $\delta^{18} \mathrm{O}$ and \pm 1.0 for $\delta \mathrm{D}$. A vaporization module converts liquid water to vapor phase in a flash process at high temperature. The vapor is then delivered into a cavity ring-down spectroscopy (CRDS) cavity for analysis. The time-based measurement system uses a near-infrared laser to quantify spectral features of molecules in the gas passed through the optical measurement cavity. Blind duplicates show excellent precision for both ${ }^{18} \mathrm{O}$ and deuterium by all three laboratories.

Samples for tritium were analyzed by Isotope Tracer Technologies in Waterloo, Ontario, by two methods: direct liquid scintillation counting (i.e. 'unenriched' analysis) for the 371 samples from 2007, 2008 and 2009; and for 162 samples from 2010 to 2011, by liquid scintillation counting after enrichment.

Enrichment (Drimmie, R.J., 2012. Analysis of Tritium in Water, Technical Procedure TP 11.0 Rev.02. Unpublished technical report, Isotope Tracer Technologies Ltd., Waterloo, Ontario, Canada, 30 pp.) first involves salt removal from the $250 \mathrm{ml}$ sample using ion exchange columns. After various checks the samples are then electrolytically reduced using $1 \mathrm{~g} \mathrm{Na}_{2} \mathrm{O}$ electrolyte, distilled to dryness, and a portion of the condensed distillate mixed with scintillant and counted for a specified period. For the enriched tritium data, 106 samples, or $64 \%$, were above the reporting limit of $0.8 \mathrm{TU}$. The unenriched data reported 136 samples, or $37 \%$, above the reporting limit of $6 \mathrm{TU}$. The median $1 \sigma$ error for the unenriched samples above the detection limit is $4.5 \mathrm{TU}$ and for the enriched data, it is $0.84 \mathrm{TU}$. Tritium, $\delta^{18} \mathrm{O}$ and $\delta \mathrm{D}$ analytical data were not published with the 2011 geochemical dataset (Hamilton 2011) and are now released in an OGS Miscellaneous Release Data (MRD) publication (Hamilton 2015).

\section{Results}

\section{Groundwater flow conditions}

Water well records indicate that just over half $(54 \%)$ of bedrock and interface wells sampled are completed within $\pm 5 \mathrm{~m}$ of the bedrock surface and $82 \%$ less than $20 \mathrm{~m}$ into bedrock. Most of the $18 \%$ of bedrock wells that are deeper than $20 \mathrm{~m}$ into rock are either in the breathing-well zone or occur near the Niagara Escarpment, where many penetrate through the subcropping bedrock unit and into underlying units. As is usual in Ontario, wells in bedrock are uncased with no well screens, whereas wells finished in the overburden part of the contact aquifer typically have short $(1-1.5 \mathrm{~m})$ well screens.

At more than half of Ambient Groundwater stations, the well cap could not be accessed because it was sealed or buried. In these cases, the static water level was estimated from the original water level recorded in the drilling record. Unlike much of the rest of southwestern Ontario, drill logs were not reliable estimates of current water level in the Devonian shale area. Thus, the water level treatment in the 'Discussion' section is for measured 
water levels only. Singer et al. (2003) reported that the potentiometric surface of the bedrock aquifer generally follows topography but it is now more accurate to say that it follows bedrock topography. Where bedrock is close to the surface near the Niagara Escarpment, water levels plummet as the escarpment is approached. The three largest buried bedrock channels, the Ipperwash, Walkerton and Brantford-Welland troughs (Gao 2011), all show significant deviations in potentiometric contours that are consistent with regional groundwater capture. The groundwater capture in the Ipperwash Trough is discussed further in the following.

\section{Isotopes of groundwater}

Samples collected from bedrock or from overburden wells within $1.5 \mathrm{~m}$ of the bedrock interface are considered here to be bedrock-influenced groundwater. The $\delta^{18} \mathrm{O}$ and $\delta \mathrm{D}$ values of these samples range from -18.64 to $-6.50 \%$ and -134.8 to $-49.4 \%$, respectively, and plot near the local meteoric water line (LMWL, $\delta \mathrm{D}=7.8$ and $\delta^{18} \mathrm{O}+9.4 \%$ ) for Simcoe, southern Ontario (IAEA/WMO 2006; Fig. 3a), suggesting meteoric-sourced groundwater, unmodified by water-rock exchange reactions. Data for both bedrock and overburden wells across the entire study area show a bimodal distribution of $\delta^{18} \mathrm{O}$ (Fig. 3b). The larger peak is centered at $-11 \%$ for overburden samples and $-12 \%$ for bedrock. A secondary peak is centered near $-17 \%$ for both overburden and bedrock wells. The latter peak is within the range of estimated glacial meltwater in the Great Lakes region (Clayton et al. 1966; McNutt et al. 1987; Long et al. 1988; Husain et al. 2004; McIntosh and Walter 2006). The larger peak is slightly lower than the center of the estimated range of modern recharge $(\sim 10 \%)$ in the Devonian shale area (Husain et al. 2004). Previously, Husain (1996) defined four groundwater zones as Pleistocene water, based on $\delta^{18} \mathrm{O}$ values $<-16 \%$ : St. Clair, Sarnia, Chatham and St. Thomas. Here a fifth zone north of central Lake Erie is defined as the Long Point zone (Fig. 4, sites 1-5, respectively). All the waters collected in these zones are from wells that penetrate thick clay aquitards. Two other areas where the influence of Pleistocene waters is apparent are on the Niagara Peninsula in waters from the Erigan Buried Channel (Fig. 4, site 6; Matheson 2011) and near Hamilton in water from three bedrock wells (Fig. 4, site 7), one of which has a $\delta^{18} \mathrm{O}$ value of $-14.53 \%$ that has since been verified $(-14.34 \pm 0.03 \%$ ). The drift thickness map (Gao et al. 2006) and well records for this site and surrounding wells indicate the water was drawn from limestone beneath 20 to $40 \mathrm{~m}$ of mostly unoxidized clay, suggesting the Pleistocene water component may result from stagnant flow.

A regression line through data for the Kettle Point Formation waters (Fig. 5) shows $\delta^{18} \mathrm{O}$ decreasing, from -11 to $-16 \%$, by approximately $0.21 \%$ for every meter of increased glacial drift thickness (i.e. depth to bedrock). Except for several very shallow modern waters, only a few samples have depths that fall beyond $\pm 10 \mathrm{~m}$ from this line. Three of these are samples that retain a slightly more Pleistocene isotopic character than those of similar depth along the trend. The remaining eight samples show the opposite; a more modern character than most other samples retrieved from similar depths. Most of the Hamilton Group samples fall on the same trend until $-16 \%$, after which $\delta^{18} \mathrm{O}$ values are consistent with the range interpreted as glacial meltwater (Desaulniers et al. 1981). The samples, for both formations, that fall off this trend are addressed in the 'Discussion' section.

A latitudinal variation in $\delta^{18} \mathrm{O}$ values of groundwater from the bedrock aquifer is apparent across the $400 \mathrm{~km}$ study area (Fig. 4), from approximately $-8.5 \%$ in the
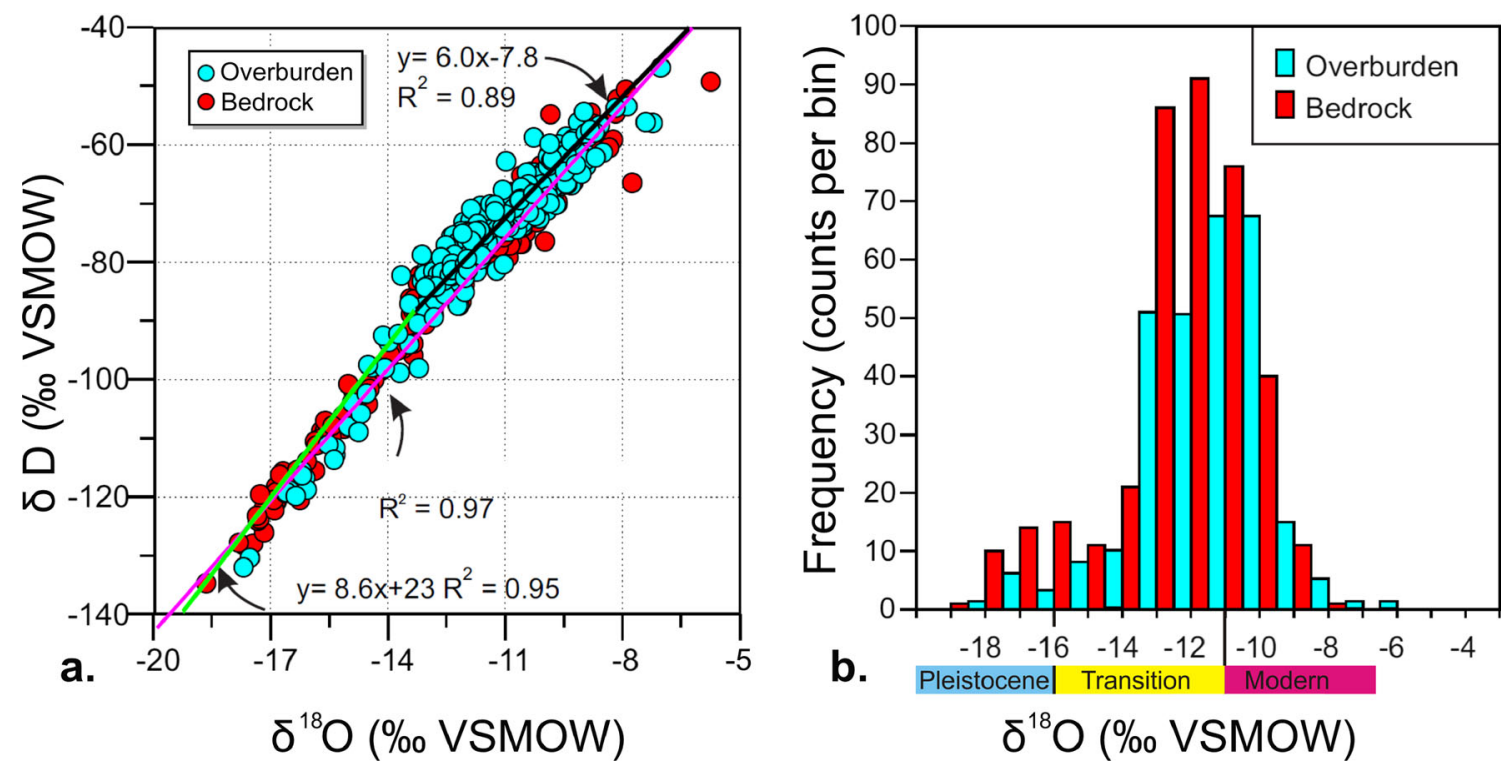

Fig. 3 a $\delta^{18} \mathrm{O}$ and $\delta \mathrm{D}$ for all samples against the local meteoric water line; $\mathbf{b}$ frequency distribution diagram of overburden vs. bedrock groundwater samples in the broader study area 


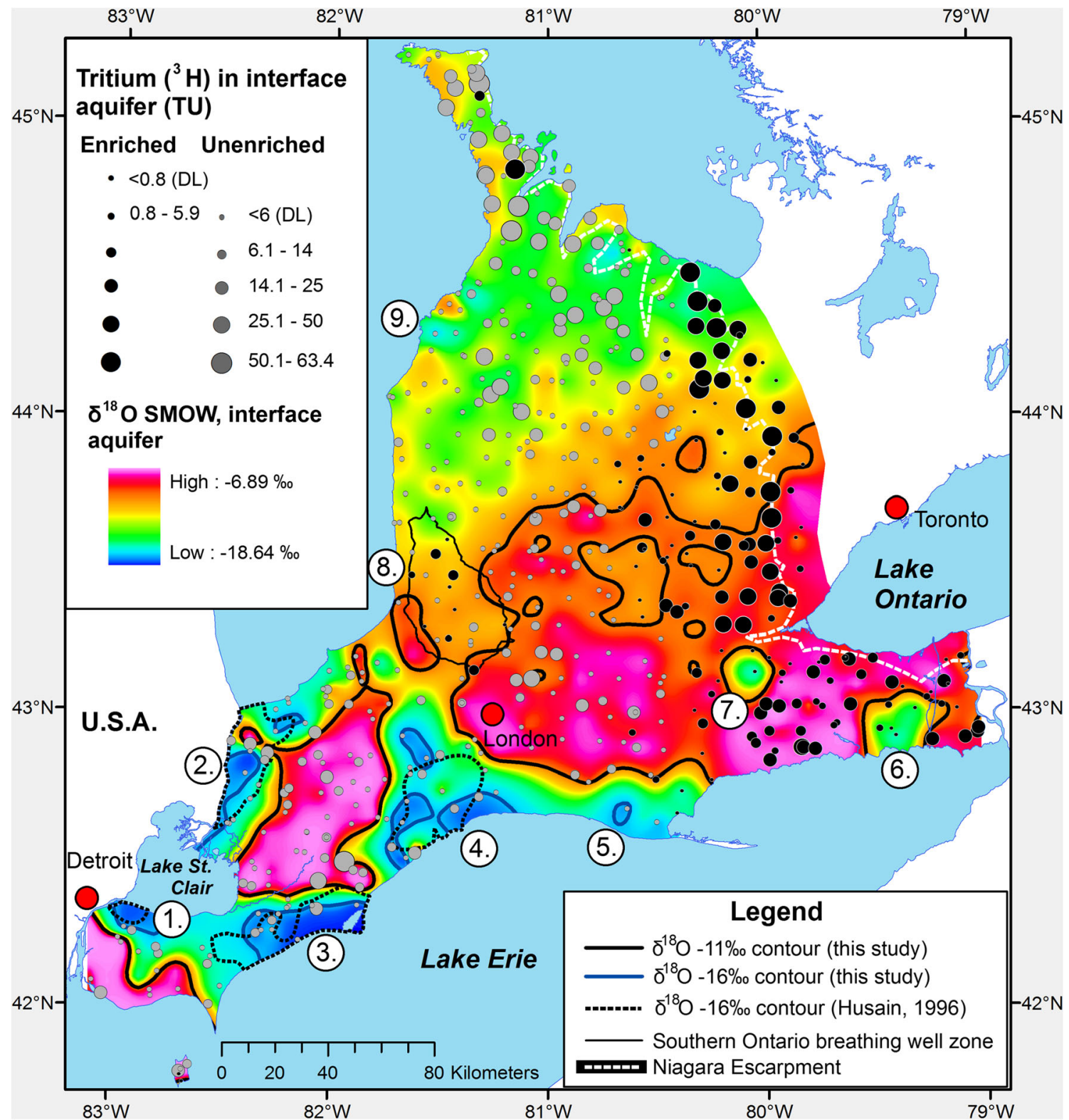

Fig. 4 Variation in $\delta^{18} \mathrm{O}$ in the bedrock aquifer in southwestern Ontario with enriched and unenriched tritium overlain. See text for explanation of numbered sites. The locations of the tritium sample sites as indicated by the proportional dots are the same as those of the $\delta^{18} \mathrm{O}$ data used to derive the colored raster image but there are $12 \%$ more $\delta^{18} \mathrm{O}$ sites and these are not shown as dots on the map. $D L$ detection limit

south to $-13.0 \%$ in the north. There is a corresponding variation in $\delta \mathrm{D}$ values. There are numerous exceptions to a simple north-south gradient in $\delta^{18} \mathrm{O}$ and $\delta \mathrm{D}$ including the Pleistocene groundwater zones. Another is the breathing-well zone (BWZ) (Fig. 4, site 8; Freckelton 2013), where samples have a lower $\delta^{18} \mathrm{O}$ character than waters to the east and west.

Figure 4 shows the tritium values for groundwater collected at the same time as the $\delta^{18} \mathrm{O}$ and $\delta \mathrm{D}$ samples. Radioactive tritium has a half-life of approximately 12.3 years and is often used to identify modern recharge vs. pre-bomb groundwater (Clark and Fritz 1997). Caution must be exercised when interpreting the unenriched tritium data, shown in grey in the western half of the Hydrogeology Journal (2015) 23: 719-739
SW Ontario study area because of the much higher detection limit and lower confidence compared with those of the enriched data.

Notwithstanding the poor precision and higher detection limits of the unenriched data, the combined tritium data show clear patterns that spatially correlate with the $\delta^{18} \mathrm{O}$ trends. The zone with ${ }^{18} \mathrm{O}$ consistent with modern precipitation, in the center of the Devonian shale area, shows sporadically elevated ${ }^{3} \mathrm{H}$ up to $50 \mathrm{TU}$. In contrast, only one sample (i.e. $<5 \%$ ) in the Pleistocene zones has a ${ }^{3} \mathrm{H}$ response that is greater than one standard deviation above the detection limit. This sample is from the north edge of the Chatham Pleistocene zone (Fig. 4, site 3), has tritium of $15 \mathrm{TU}$ and has a corresponding $\delta^{18} \mathrm{O}$ value of 


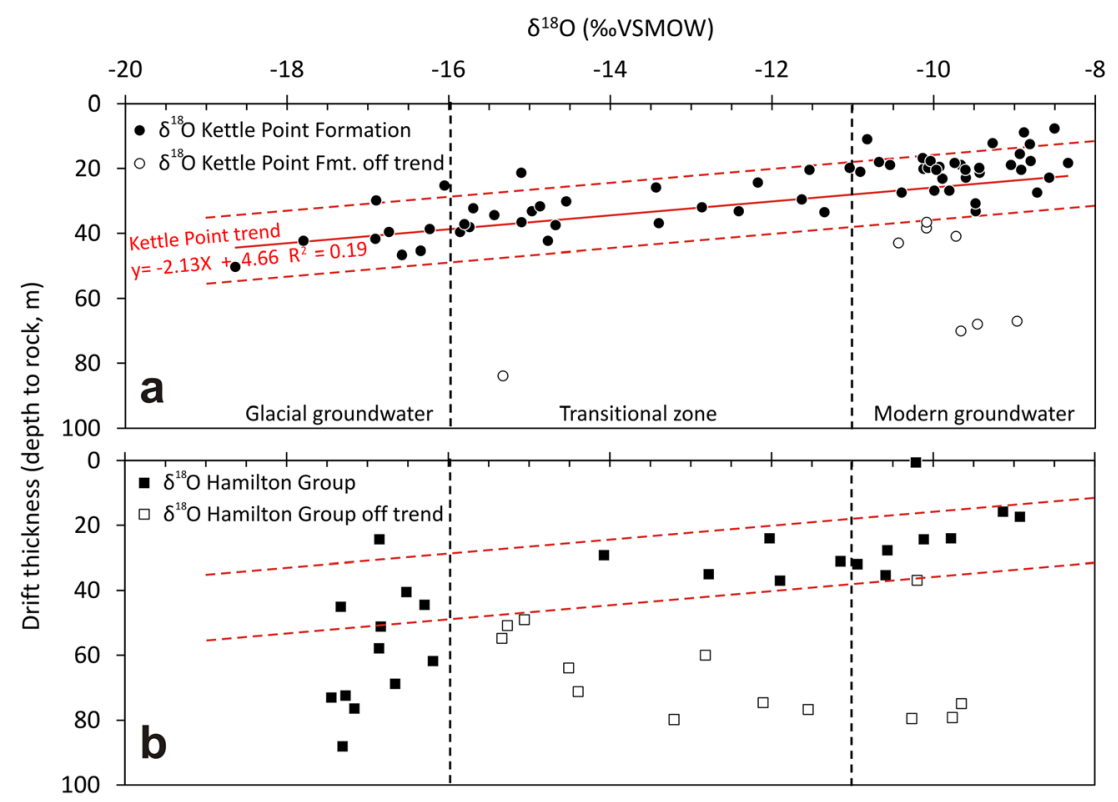

Fig. $5 \delta^{18} \mathrm{O}$ vs. drift thickness for a Kettle Point Formation and $\mathbf{b}$ Hamilton Group samples. The trend defined by a regression line through the Kettle Point data is apparent in the Hamilton Group data, down to the $-16 \%$ line, after which all waters have a Pleistocene character. The values that fall deeper than $10 \mathrm{~m}$ below this line are shown in white and treated in the 'Discussion' section. The $R^{2}$ value (coefficient of determination) of the Kettle Point regression line is low because of the presence of the outliers and the low slope of the trend

$-16.6 \%$. This very low $\delta^{18} \mathrm{O}$ value suggests that the elevated tritium in this sample is unlikely to result from mixing of younger tritiated water with fossil water. It may result from the poor analytical precision since the value is within 2 standard deviations of the unenriched detection limit and therefore up to $5 \%$ of data would be expected to report concentrations as high as $15 \mathrm{TU}$.

Eastward from the Devonian shales to the Niagara Peninsula, areas exhibiting high $\delta^{18} \mathrm{O}$ values in groundwater also exhibit elevated tritium. On the peninsula itself, samples from the two buried valleys (Fig. 4, sites 6 and 7) show a consistently low and mostly undetectable tritium $(<0.8 \mathrm{TU})$ by the superior enrichment method. A wide zone of elevated and northward increasing tritium concentrations occurs along the Niagara Escarpment. This represents the active bedrock flow systems associated with the topographically elevated bedrock surface within $30 \mathrm{~km}$ west of the escarpment.

In the north half of the study area a swath of elevated tritium concentrations by both enriched and unenriched methods may be related to eastward dispersion of tritium from the Bruce Nuclear Station (Fig. 4, site 9), a heavywater facility and the world's largest nuclear plant by power output. However, the values are elevated only relatively; the highest value, at $63.4 \mathrm{TU}$, is 3 orders of magnitude below the Canadian drinking-water limit for tritium of $7,000 \mathrm{~Bq} / \mathrm{L}(59,000 \mathrm{TU})$.

\section{Major ion and trace element geochemistry}

The major ion proportions and concentrations for the various units in southwestern Ontario are summarized in Figs. 6 and 7, respectively; and the concentrations of selected trace elements are summarized in Fig. 8. The data clearly show the relationship between host lithology and groundwater geochemistry in bedrock. The shale waters stand out from those of the carbonate units as having higher $\mathrm{Na}, \mathrm{K}, \mathrm{Cl}, \mathrm{NH}_{4}$, iodide, DOC, $\mathrm{pH}$ and total dissolved solids (TDS) and are predominantly $\mathrm{Na}-\mathrm{Cl}$ to $\mathrm{Na}-\mathrm{HCO}_{3}$-type (Fig. 6). The Devonian shale waters are generally higher in $\mathrm{pH}, \mathrm{Na}, \mathrm{Cl}, \mathrm{DOC}$ and iodide than the Ordovician shale waters and much lower in $\mathrm{Ca}, \mathrm{Mg}, \mathrm{SO}_{4}$, $\mathrm{CO}_{2}$ and $\mathrm{K}$. The Kettle Point Formation (No. 1, Fig. 7) stands out as having waters with the highest $\mathrm{Na}$ and $\mathrm{HCO}_{3}$ of any unit in the study area and the lowest $\mathrm{SO}_{4}$ and $\mathrm{H}_{2} \mathrm{~S}$.

Like $\mathrm{SO}_{4}, \mathrm{H}_{2} \mathrm{~S}$ is mostly undetectable in the Devonian shale waters (Fig. 8). For samples that do contain $\mathrm{H}_{2} \mathrm{~S}$ (Table 2): (1) $\mathrm{H}_{2} \mathrm{~S}$ is at paradoxically high concentrations, (2) $\mathrm{SO}_{4}$ is always present, (3) the concentrations of $\mathrm{CH}_{4(\mathrm{aq})}$ are much lower, and (4) the median molar ratio of $\mathrm{H}_{2} \mathrm{~S}: \mathrm{SO}_{4}$ is greater than one, which is far higher than in other units. $\mathrm{H}_{2} \mathrm{~S}$ is uniformly higher in the underlying Dundee Formation where $73 \%$ of samples had detectable values and the median of $0.26 \mathrm{mg} / \mathrm{L}$ was the highest of any unit.

The Ordovician shales have an overall median $\mathrm{H}_{2} \mathrm{~S}$ concentration that is below detection but have a greater number of samples with detectable values (Table 2). Despite this, the ratio of $\mathrm{H}_{2} \mathrm{~S}: \mathrm{SO}_{4}$ for detectable values is three orders of magnitude lower than for the Devonian shales.

The carbonate units host waters that are mostly $\mathrm{Ca}-$ $\mathrm{HCO}_{3}$ to $\mathrm{Ca}-\mathrm{SO}_{4}$-type with higher dissolved $\mathrm{CO}_{2}$ than the shales. The Salina and Bass Island evaporitic units are $\mathrm{Ca}-\mathrm{SO}_{4}$ dominant with high to very high concentrations of $\mathrm{Ca}, \mathrm{Mg}$ and $\mathrm{SO}_{4}$. 


\section{Discussion}

\section{Water level recovery and drawdown}

The pre-anthropogenic potentiometric surface of the bedrock interface aquifer in the Devonian shale area was shallow and generally paralleled topography, but anthropogenic pumping in the decades following 1940 impacted water levels (Husain et al. 2004). Current water levels in the interface aquifer are significantly different from those of the 1960s when the effects of regional domestic and farm groundwater usage were most apparent (Fig. 9a). Water level recovery in the Sarnia-Lake St. Clair area was first noted by Husain (1996) for the period from the early 1980s to 1995 and has progressed further since that time. In the western half of the shale area, the potentiometric surface has recovered since the 1960s in a broad U-shaped area from the south shore of Lake Huron to the south and eastern shores of Lake St. Clair to the north shore of Lake Erie (Fig. 9a). The part of the aquifer where the potentiometric surface is beneath the average water level in the three lakes-175 $\mathrm{m}$ above sea level (ASL) - has shrunk significantly.

In an area west of London and St. Thomas, water levels have dropped by over $30 \mathrm{~m}$ since the 1960s (Fig. 9a). Changes have occurred eastward to at least London, where the $250 \mathrm{~m}$ contour has moved east of the city from $10 \mathrm{~km}$ west in the 1960s. These trends in changing potentiometric surface are influenced by the bedrock topography (Fig. 9b), as the most significant changes have been in the Ipperwash Trough, which extends the $80 \mathrm{~km}$ between lakes Huron and Erie. East of the Ipperwash Trough, drawdown of the potentiometric surface is less significant. Geological maps and water well records show a thick glaciolacustrine clay and fine-grained till aquitard overlying the fractured rock contact zone, which forms the dominant bedrock aquifer. Because of the aquitard, recharge of the thin interface aquifer in the Ipperwash Trough must occur laterally over significant distances, or must come from storage in the aquitard (Husain et al. 2004). This restricts the rate of replacement as domestic
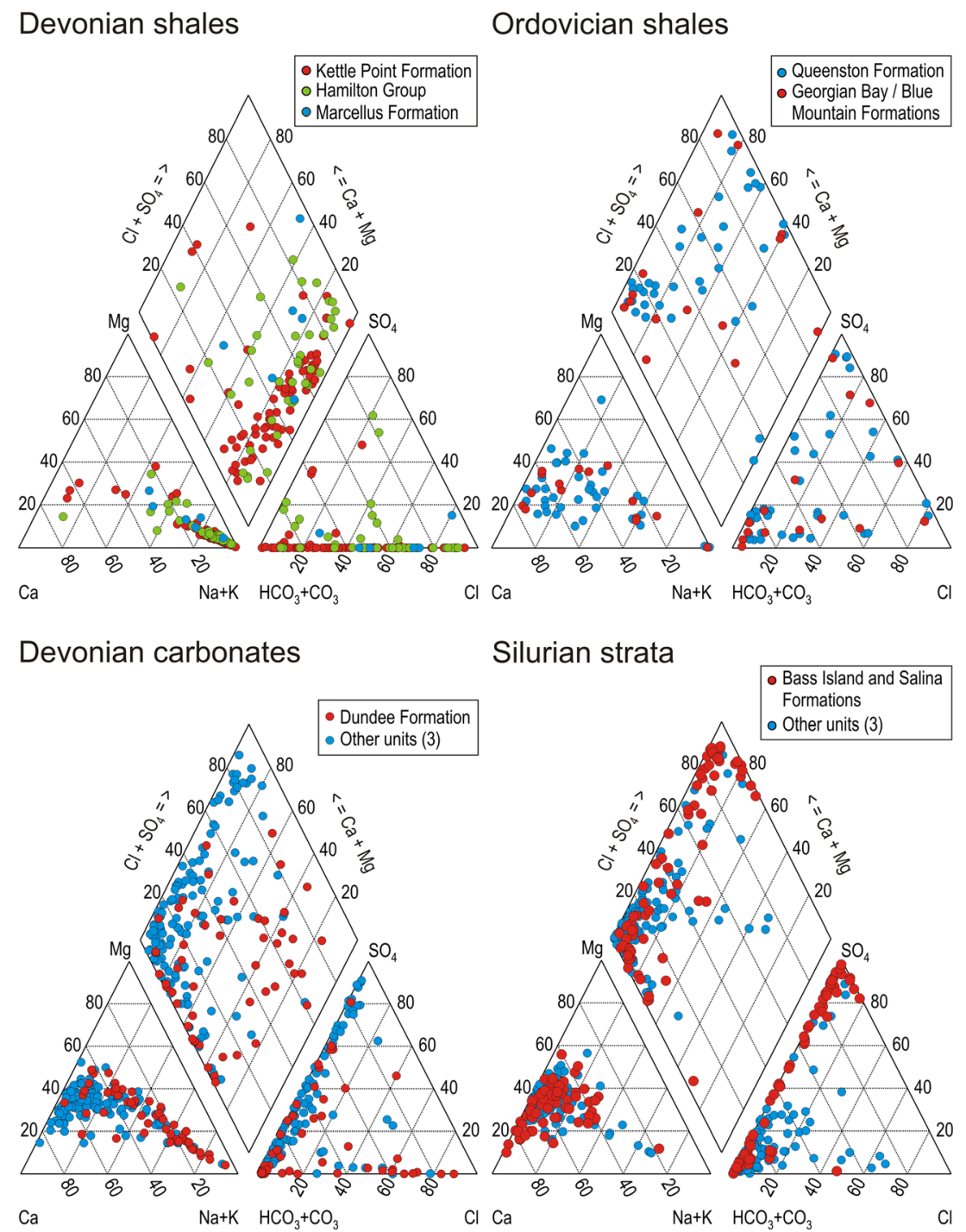

Fig. 6 Piper plots for Devonian shales, Ordovician shales, Devonian carbonate units and Silurian strata 

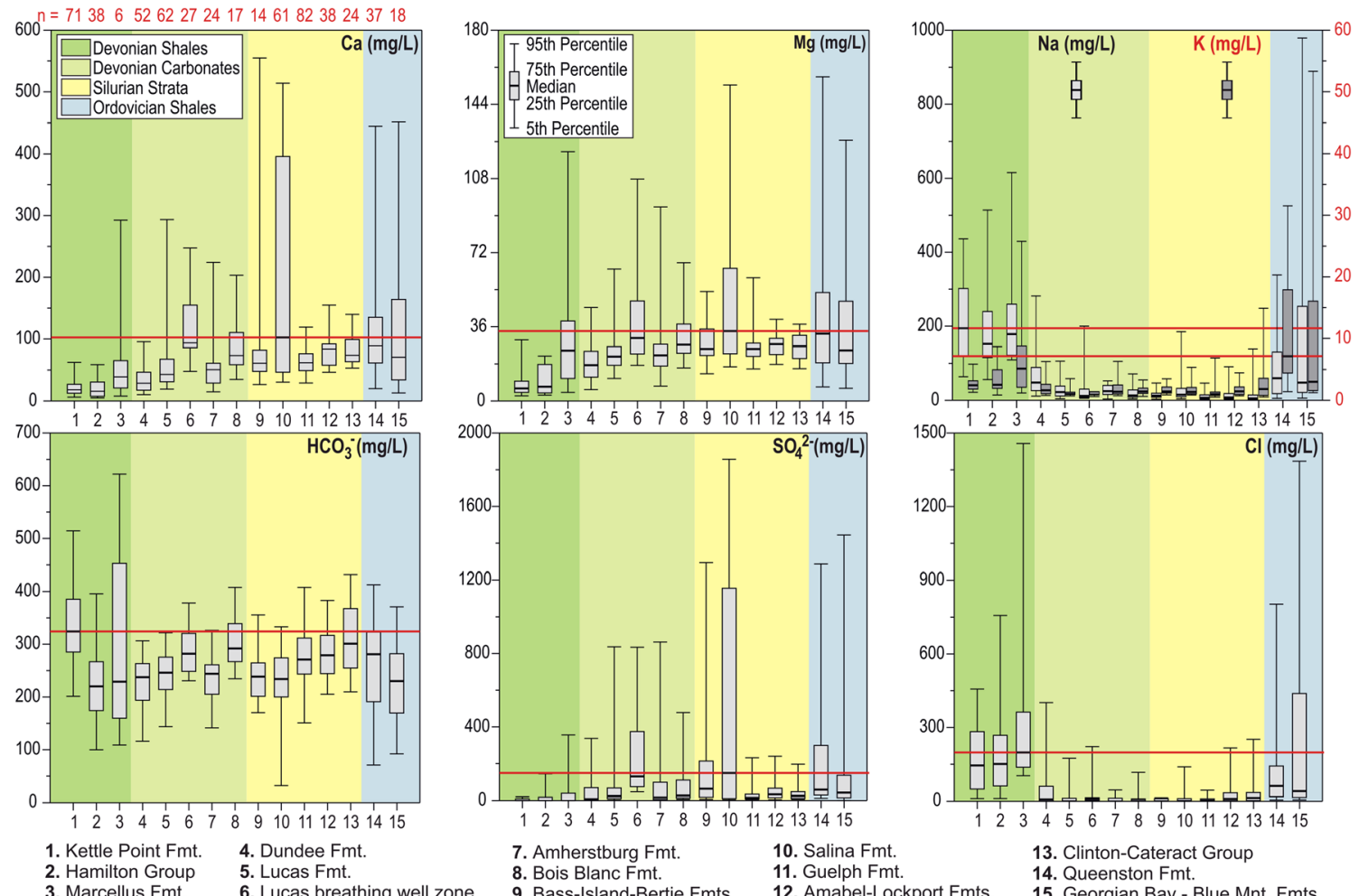

Fig. 7 Box and whisker plots for major elements by geological unit, organized by increasing age from left to right. The central black line in each box is the median for all data in that geological unit; the bold red line is the maximum median of all units in the study area. 50 samples from 6 geological units on Niagara Peninsula were removed from the database due to possible anthropogenic influence. The value " $n$ " is the number of samples collected in each unit
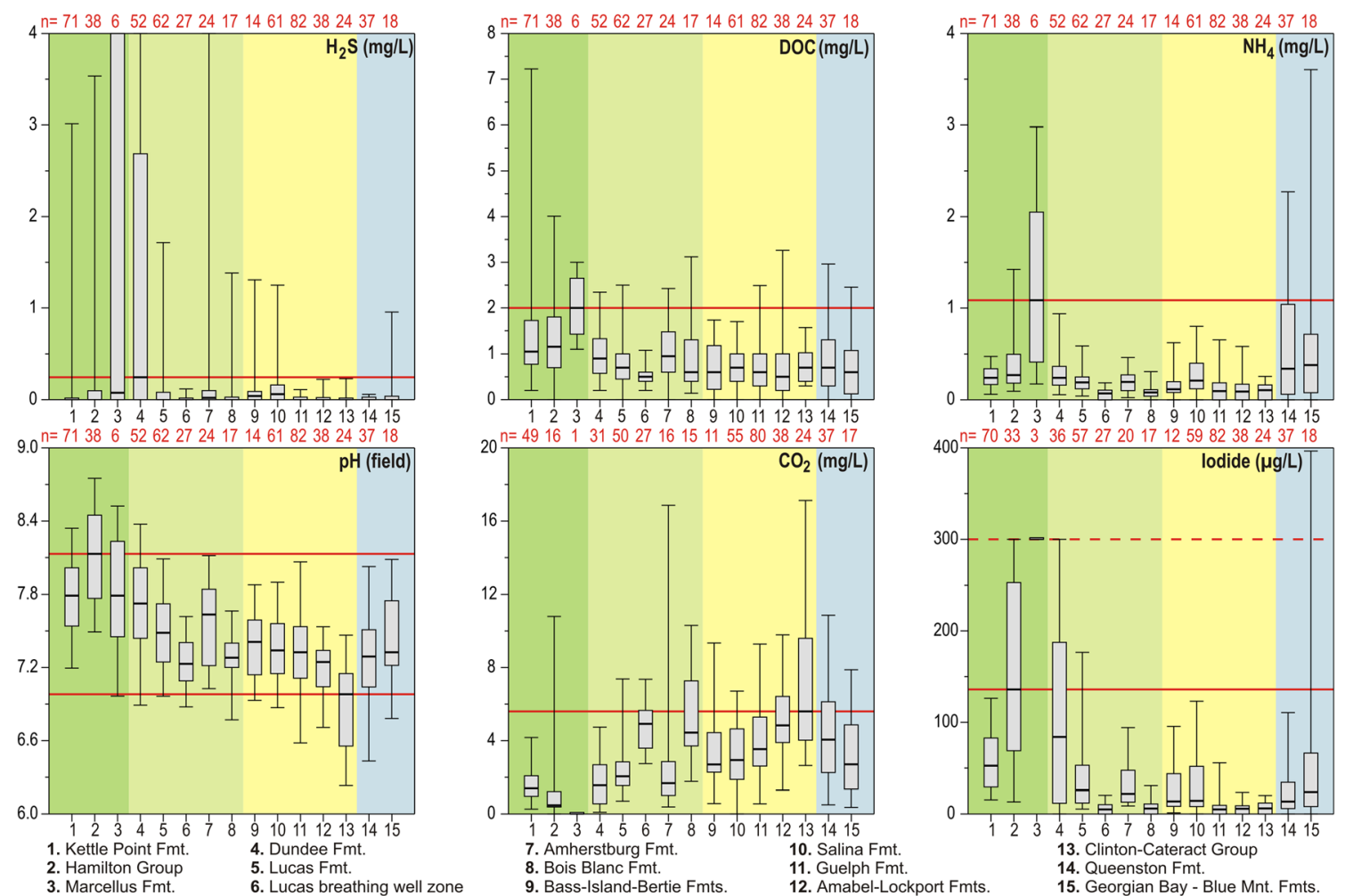

Fig. 8 Box and whisker plots for selected trace elements by geological unit, organized by increasing age from left to right. The value " $n$ " is the number of samples collected in each unit and analyzed for the indicated parameters. See the caption for Fig. 7 for further explanation 
and farm wells continue to withdraw water. Water levels in the contact aquifer in the northwestern Ipperwash Trough are similar to those in the breathing-well zone, but the hydraulic relationship between the two aquifers is not clear and is the subject of ongoing investigation.

By about $10 \mathrm{~km}$ west of the Ipperwash buried escarpment, in the middle of the shale area, the potentiometric surface has changed very little since the 1960s (Fig. 9b). This region corresponds to a thinner drift area where recharge is rapid. Despite recovery near the lakes in the west, northwest and south, continued pumping of the aquifer west of London may soon deplete the interface aquifer in the Ipperwash Trough beyond viable use.

\section{Regional pumping and shrinkage of the Pleistocene groundwater zones}

Figure 4 shows the -11 and $-16 \% \delta^{18} \mathrm{O}$ contours that outline the current state of the Sarnia, St. Thomas, Chatham and St. Clair Pleistocene groundwater zones as originally defined by Husain (1996). Also shown is Husain's original outlining of the zones, but for simplicity his modern and 'transition' zones are not shown. The Pleistocene zones, as defined by the $-16 \% \delta^{18} \mathrm{O}$ contour, have shrunk dramatically; the Sarnia zone is one third the size that it was in the 1970s and 1980s when most of the earlier data were collected. The St. Thomas zone is also less than half the size, although there are areas of apparent expansion near Lake Erie. The Chatham zone is smaller overall but it too shows apparent expansion in the part closest to Lake St. Clair. The St. Clair zone is significantly larger, although this is based on only four samples in or near the zone. The central modern zone, as defined by the $-11 \%$ contour (Figure 2.5 in Husain 1996) has expanded only slightly except in the northwest near Sarnia (Fig. 4). Here, a new $200 \mathrm{~km}^{2}$ area of modern water has divided the Sarnia Pleistocene zone into two much smaller parts.

Husain et al. (2004) postulated that water removed due to pumping in the Sarnia Pleistocene zone was supplied from either lateral flow or aquitard storage. The significant contraction of the St. Thomas and particularly the Sarnia Pleistocene zones after only 30 years argues against the latter possibility because aquitard porewaters also retain a Pleistocene isotopic composition (Fig. 3; Weaver et al. 1995; Desaulniers et al. 1981; Husain 1996). Under natural conditions, the Pleistocene zones have lasted for 10,000 years, and were expected less than two decades ago (Husain 1996) to persist for millennia. Assuming no aquifer injection, both continued pumping and aquifer recovery have reduced the size of the Sarnia and St. Thomas zones at a rate that may eradicate them in decades.

The apparent local expansion of the Pleistocene zones may partly be due to different sample distribution and density of the Husain sampling and this study's. However, the expansion is apparent mostly near the lakes and in some cases in areas that previously had a potentiometric surface in the contact aquifer below lake level. This suggests that replacement of groundwater under the thick clays adjacent to Lakes Erie and St. Clair may have been bi-directional with water derived from both the active flow system in the central peninsula and the stagnant contact aquifer under the lakes. Water in the contact aquifer beneath the lake retains a Pleistocene isotopic composition as noted in sediments under lakes Erie and Ontario (Drimmie et al. 1993). The result of recharge from both the lakeward and landward sides would be to increase the size of the Pleistocene zones near the lake and the modern zone in the center of the peninsula and shrink the transition zone between the two areas and this is generally consistent with observations.

Most (87) Devonian shale waters fall on a linear trend of decreasing $\delta^{18} \mathrm{O}$ values with depth (Fig. 5). However, 13 Hamilton Group and 8 Kettle Point samples have isotopic compositions that are more modern than most samples of a similar depth. All but one of these samples fall into three geographic clusters (Fig. 10):

1. A lobe of sub-modern water south of Sarnia (A on Fig. 10)

2. Modern to sub-modern waters (B on Fig. 10) around the periphery of the central modern water zone, including a lobe of modern water underlying the village of Ridgetown (C on Fig. 10), $25 \mathrm{~km}$ east of Chatham.

3. The sub-modern or mixed waters in the NW-SE trending Ipperwash Trough west of London (D on Fig. 10).

The off-trend samples cluster in areas where modern or mixed waters have expanded toward the Pleistocene zones in the last three decades. These samples therefore represent waters that have moved under the influence of pumping or aquifer recovery from shallower, more active flow areas, to formerly sluggish flow areas. During this process, younger waters have mixed with older waters to varying degrees.

Thus the data show a flow system in the contact aquifer that ranges from active with modern ( $>1950$ s) groundwater in the center of the peninsula to stagnant with ancient water near the lakes and with flow and groundwater replacement extensively influenced by regional non-point source pumping of domestic and farm wells. Whereas shrinkage of the Sarnia and Chatham Pleistocene zones is occurring during a decades-long period of aquifer recovery, shrinkage of the St. Thomas zone is accompanied by large-scale drawdown apparently due to ongoing pumping. The shrinkage of the Pleistocene zones is accompanied by changes in groundwater chemistry, which in turn may influence gas concentrations as discussed in the next section.

\section{Groundwater geochemistry}

Figure 11 displays the spatial patterns of major ion composition in waters in southwestern Ontario after the 

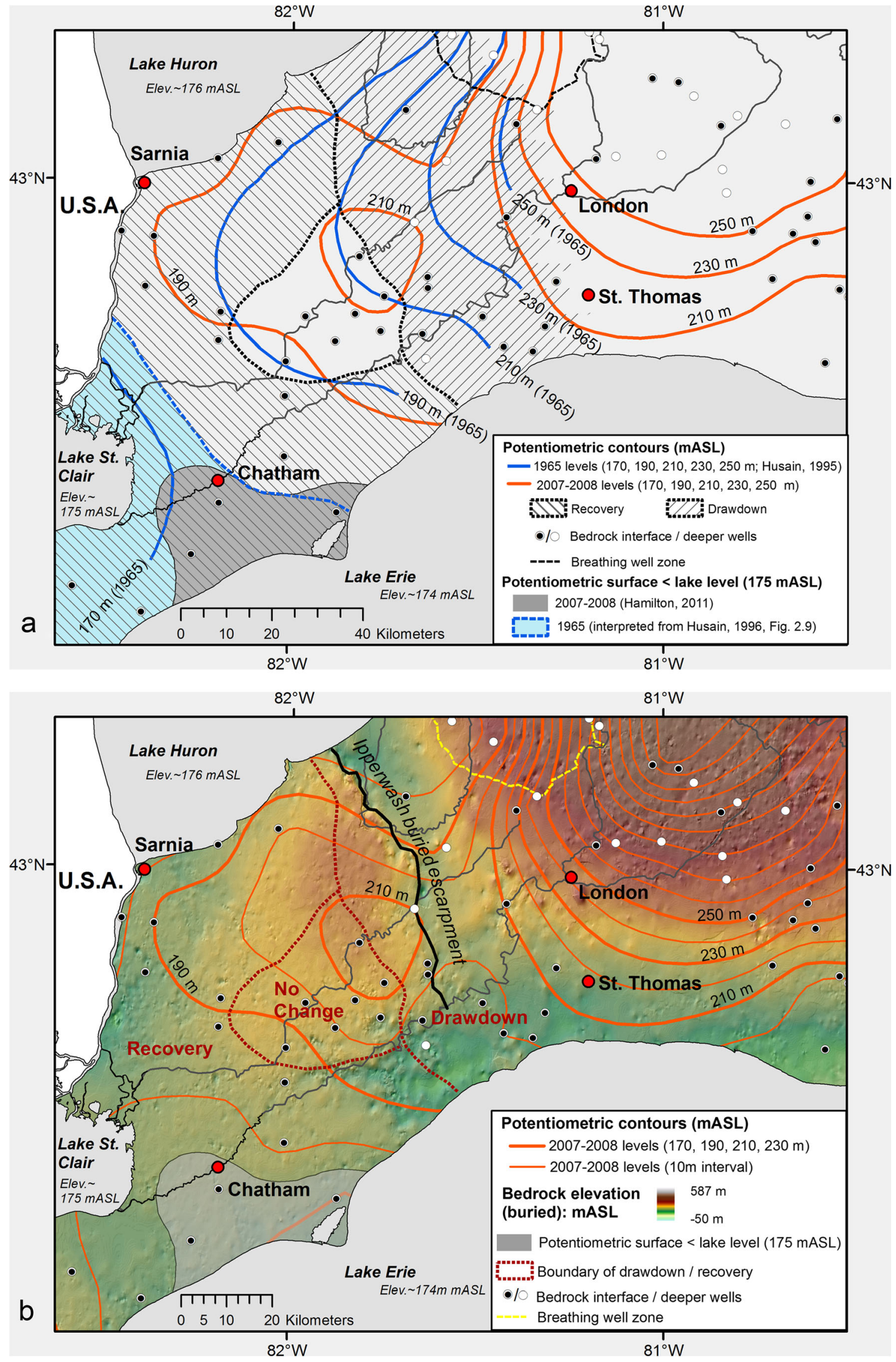
4 Fig. 9 a Modern water levels (Hamilton 2015) measured from 2007 to 2010 versus those in the 1960s (Husain 1996) in the Devonian shale area and areas of drawdown and recovery. b Modern water levels versus bedrock topography. Bedrock topography is by Gao et al. (2006)

method of Peeters (2014). In the Devonian shale area the dominant cation is sodium (green) and changes sharply to Ca-Mg-dominant (white through $\mathrm{red} /$ magenta) at the boundaries of the shale area. Comparison with the anion plot indicates that the sodium is derived from both cation exchange and formational brines. Recharged waters in the center of the peninsula dissolve carbonate materials in glacial sediments after which $\mathrm{Ca}-\mathrm{Mg}$ in water is rapidly ion-exchanged with $\mathrm{Na}$, presumably by sorbtion to clay minerals in black-shale tills (Fitzgerald et al. 1979) close to bedrock. Waters with a modern isotopic composition (inside the $-11 \% 0 \delta^{18} \mathrm{O}$ contour, Fig. 11), that often contain tritium, show a strong bicarbonate character (red), whereas the older waters in the Pleistocene zones show a strong $\mathrm{Cl}$ character (green). Between the two areas, the composition transitions from one to the other; i.e. from red to orange to yellow to light green. However, many areas that formerly had Pleistocene-aged waters (dashed line, Fig. 11) have a mixed or mostly bicarbonate character which further supports the isotopic data, indicating that waters have been mixed or replaced in the last three decades.

Figure 12 shows, for the Kettle Point Formation and Hamilton Group, the relationship between various parameters for on-trend and off-trend (Fig. 5) waters as a function of glacial drift (predominantly clay) thickness. The on-trend data show evidence of increasing cation exchange with depth, as demonstrated by the charge equivalence ratio $(\mathrm{Na}-\mathrm{Cl}) / \mathrm{HCO}_{3}{ }^{-}$, and increasing $\mathrm{Cl}$ content. The increasing $\mathrm{Cl}$ trend with depth results from incorporation of residual formational brine in the shale that increases with depth in southwestern Ontario (Hobbs et al. 2008) to greater than $100,000 \mathrm{mg} / \mathrm{L}$ by $200-300 \mathrm{~m}$. The drop in both parameters in the deepest bins may be due to inclusion of samples from the Ipperwash Trough where the Kettle Point Formation is absent and the Hamilton Group is typically less than $25 \mathrm{~m}$ thick, thus limiting the shale-related brine component. This results in a poorer correlation with depth for both parameterscorrelation coefficients $(\mathrm{CC})=0.35$ and 0.32 , respectively - than if the deepest bins are excluded (0.4 and 0.43). The same depth intervals for the off-trend samples show consistently lower cation exchange and $\mathrm{Cl}$ content and no correlation with depth $(\mathrm{CC}=-0.02$ and -0.01 , respectively).

Iodide shows more similar correlations with depth in on-trend and off-trend waters $(\mathrm{CC}=0.7$ and 0.29 , respectively) with lower concentration medians for the younger (off-trend) waters only in the two deepest bins. In marine and estuarine environments, iodine is concentrated into phytoplankton and other marine plants (Moisan et al. 1994; Osborn et al. 2012) and correlates with organic matter in marine sediments (Elderfield and Truesdale 1980; Malcolm and Price 1984), marine sedimentary rocks and, in particular, organic shales (Collins et al. 1971; Worden 1996). Upon burial, iodine can remain conservative in the sediments (Upstill-Goddard and Elderfield 1988), although it changes speciation during digenesis.

Like $\mathrm{Cl}$, the elevated iodide may partly result from mixing with formation waters (Osborn et al. 2012). However, the closer correlation for iodide than $\mathrm{Cl}$ between old and young waters suggests another contemporary geochemical process is contributing to the off-trend concentrations. Iodide concentrations for both on and off-trend samples in the three deepest bins exceed that of seawater (Hem 1986) by a factor of more than two, despite almost all waters being potable, and are ten times higher than the median for groundwater in southwestern Ontario (12 $\mu \mathrm{g} / \mathrm{L}$; Hamilton 2015). This suggests that active decomposition of organic matter in the host shales may be releasing iodide.

The $\mathrm{pH}$ of both sets of waters (Fig. 12) shows close coincidence with increasing depth and a significant rise of one $\mathrm{pH}$ unit as glacial cover exceeds $60 \mathrm{~m}$. The four carbon parameters-DIC, $\mathrm{HCO}_{3}, \mathrm{CO}_{2(\mathrm{aq})}$, and $\mathrm{CH}_{4(\mathrm{aq})}$ also show strong coincidence in trends as depth increases; in the case of the first three (oxidized) species, they drop significantly. $\mathrm{CH}_{4(\mathrm{aq})}$ increases to almost saturation by $15 \mathrm{~m}$ depth and remains at a similarly high concentration with depth. There is also a close spatial correlation between elevated $\mathrm{CH}_{4(\mathrm{aq})}$ and the organic rich shales and overburden that overlies the shales (Hamilton 2011; McIntosh et al. 2014). The very high concentration of the final bin is due to bursts of free bubbles encountered during collection of several deep samples, resulting in higher dissolved methane concentrations. Such bursts were more common with deeper samples because of the greater pressure reduction as water is pumped from depth.

Despite the poor precision of unenriched tritium, it correlates with other parameters in the off-trend (younger) samples. The strongest negative correlation is with iodide $(\mathrm{CC}=-0.52)$, then $\mathrm{pH}(-0.37)$, cation exchange $(-0.29)$, and $\mathrm{CH}_{4}(-0.29)$. It positively correlates with $\mathrm{CO}_{2}(0.36)$ and shows poor or no correlation with $\mathrm{Cl}(-0.22), \mathrm{HCO}_{3}(-0.17)$, and DIC (-0.06). As expected, in the on-trend (older) samples, tritium shows poor or no correlation with the previously noted parameters (all poorer than \pm 0.21 ). The negative correlation with tritium in the younger samples indicates that the geochemical processes controlling element concentrations are ongoing and contemporary and modify the chemical signature of bedrock groundwater on a time scale of no more than several decades.

With respect to $\mathrm{Cl}$ concentration and cation exchange, slow-acting diffusion, and sluggish adjective mixing have impacted the younger (off-trend) waters but because of limited time and distance, the equilibration of groundwater with the host rock is not complete. The closer co-variability of old and young (i.e. on and off-trend) waters for the carbon parameters, $\mathrm{pH}$ and iodide suggests that their concentrations in solution are controlled by processes other than simple mixing. Some forms of methanogenesis based on labile organic carbon directly utilize $\mathrm{CO}_{2}$ and other inorganic 
Table 2 Sulfur species vs. methane for four stratigraphic groups

\begin{tabular}{|c|c|c|c|c|c|c|c|c|c|c|}
\hline & \multirow[t]{2}{*}{ Number } & \multicolumn{3}{|c|}{$\mathrm{H}_{2} \mathrm{~S}(\mathrm{mg} / \mathrm{L})$} & \multicolumn{2}{|c|}{$\mathrm{SO}_{4}{ }^{2-}(\mathrm{mg} / \mathrm{L})$} & \multicolumn{2}{|c|}{$\mathrm{M} \mathrm{H}_{2} \mathrm{~S} / \mathrm{M} \mathrm{SO}_{4}{ }^{2-}$} & \multicolumn{2}{|c|}{$\mathrm{CH}_{4} \mathrm{Md}(\mathrm{ppmw})$} \\
\hline & & $\%>\mathrm{DL}$ & $\begin{array}{l}\text { Md } \\
\text { (All) }\end{array}$ & $\begin{array}{l}\mathrm{Md} \\
(>\mathrm{DL})\end{array}$ & $\%>\mathrm{DL}$ & $\begin{array}{l}\text { Md } \\
\text { (all) }\end{array}$ & $\begin{array}{l}\text { Avg } \\
(>\mathrm{DL})\end{array}$ & $\begin{array}{l}\mathrm{Md} \\
(>\mathrm{DL})\end{array}$ & $\begin{array}{l}\mathrm{SO}_{4}{ }^{2-}<1 \mathrm{mg} / \\
\mathrm{L}\end{array}$ & $\begin{array}{l}\mathrm{SO}_{4}{ }^{2-}>1 \mathrm{mg} / \\
\mathrm{L}\end{array}$ \\
\hline $\begin{array}{l}\text { Devonian } \\
\text { shales }\end{array}$ & 115 & $24 \%$ & $<0.01$ & 0.43 & $30 \%$ & $<0.04$ & 2.81 & 1.37 & 33.4 & 4.5 \\
\hline $\begin{array}{l}\text { Dundee } \\
\text { Formation }\end{array}$ & 51 & $73 \%$ & 0.260 & 0.93 & $90 \%$ & 7.4 & 1.90 & 0.38 & 14.5 & 0.1 \\
\hline $\begin{array}{l}\text { Ordovician } \\
\text { shales }\end{array}$ & 55 & $35 \%$ & $<0.01$ & 0.03 & $95 \%$ & 56.2 & 0.56 & 0.001 & 4.0 & 0.0 \\
\hline $\begin{array}{l}\text { All other } \\
\text { units }\end{array}$ & 322 & $48 \%$ & $<0.01$ & 0.08 & $99.7 \%$ & 26.47 & 0.14 & 0.01 & 4.4 & 0.0 \\
\hline
\end{tabular}

$D L$ method detection limit, $M d$ median value

carbon species as electron acceptors (e.g. Ferry 1992), the outcome of which is to increase $\mathrm{pH}$ and $\mathrm{CH}_{4}$ and consume dissolved, oxidized inorganic carbon species. This is consistent with observations as is the increase in iodide, which may be liberated as organic matter is consumed.

The Dundee Formation bituminous carbonates also have abundant organic matter and have the highest $\mathrm{CH}_{4(\mathrm{aq})}$ concentrations of any unit other than the Devonian shales (Table 2). However, these occur in the minority of cases in the Dundee Formation where the $\mathrm{SO}_{4}$ is low or absent; where $\mathrm{SO}_{4}$ does occur, $\mathrm{H}_{2} \mathrm{~S}$ is elevated and $\mathrm{CH}_{4(\mathrm{aq})}$ concentrations (Hamilton 2015) are low. The lack of significant methane in the Ordovician shales may be due to a combination of a greater abundance of competing electron acceptors (e.g. $\mathrm{SO}_{4}, \mathrm{Fe}$ ) and lower quantities and/ or less labile organic matter (McIntosh et al. 2014). The evidence of ongoing geochemical processes related to biogenic gas production in the shales, and the general similarity between the concentrations of gas in older and younger waters with increasing depth, further supports the theory (e.g. McIntosh et al. 2014) that biogenic gas production in the shales is contemporary and rapid.

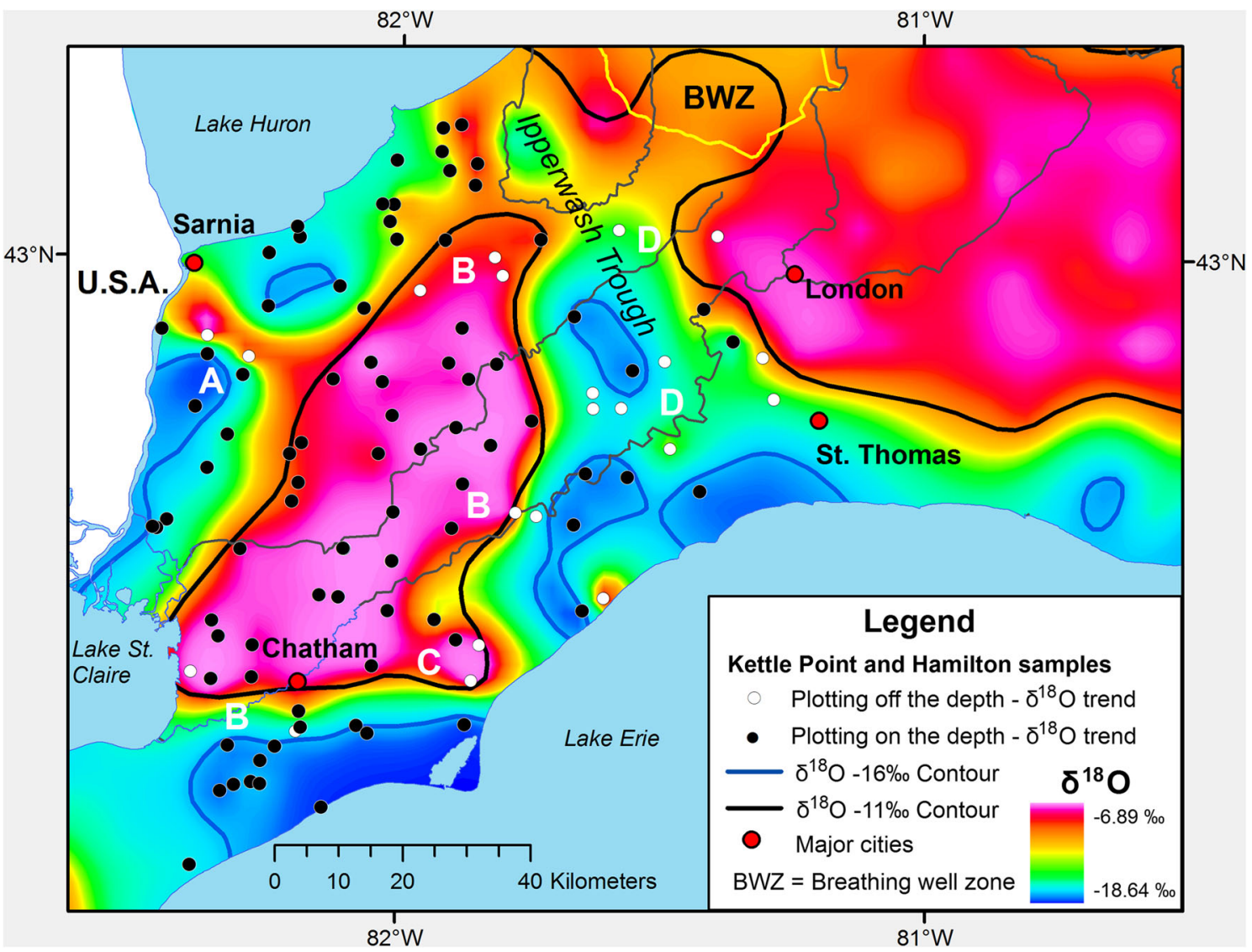

Fig. $10 \delta^{18} \mathrm{O}$ in Devonian shale area for bedrock and interface wells. Dots represent samples from the Kettle Point Formation and Hamilton Group. Black dots are samples on the $\delta^{18} \mathrm{O}$-depth trend (Fig. 5); white samples are off-trend. Sites designated with letters are specific areas that have a larger component of modern water than is typical for samples at the same depth and may be related to invigoration of the flow system due to anthropogenic pumping. $A=$ Sarnia younger-water lobe; $B=$ periphery of central modern water zone; $C=$ Ridgetown modern-water lobe; and $D=$ Ipperwash Trough transitional-waters 


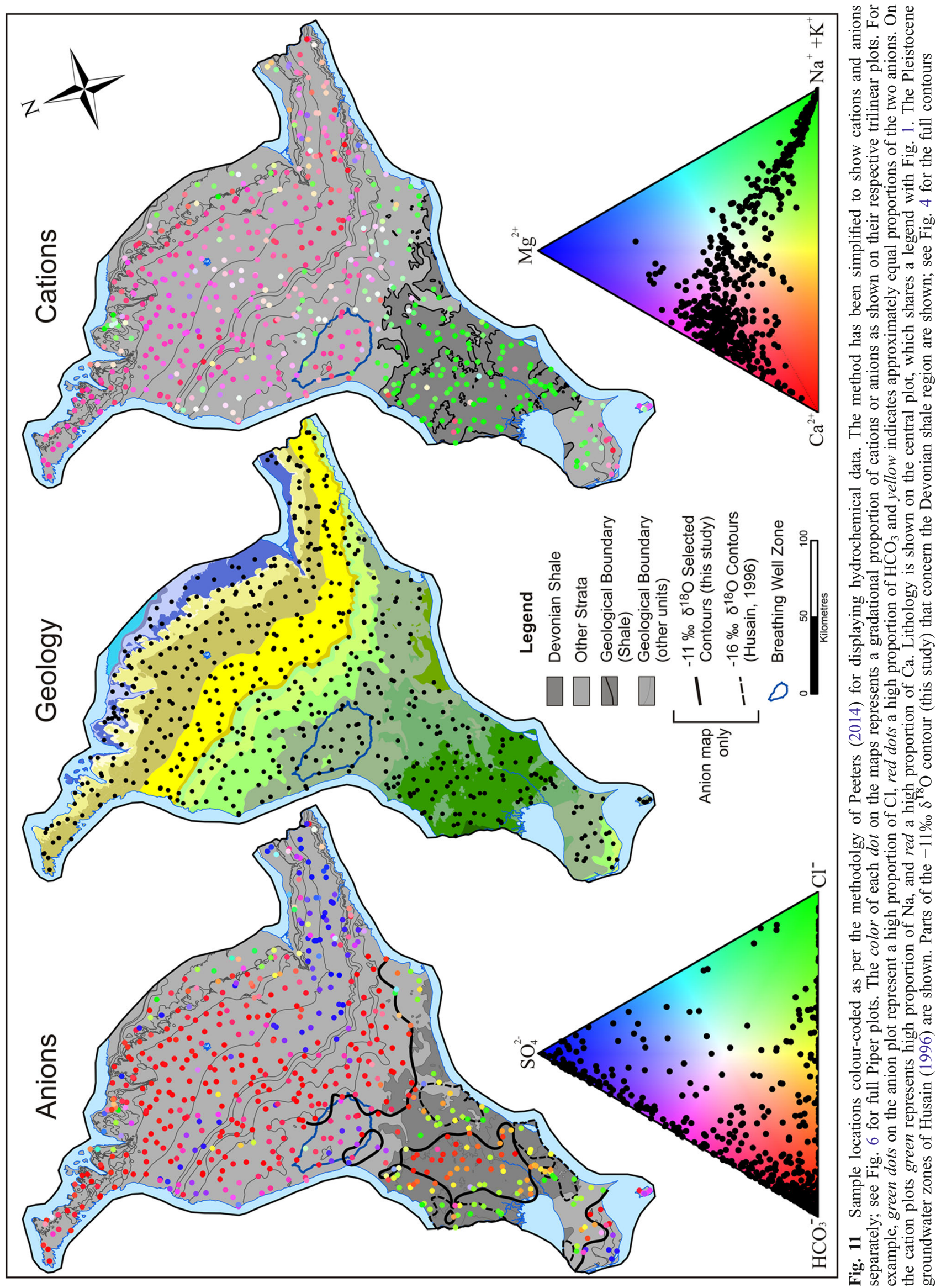



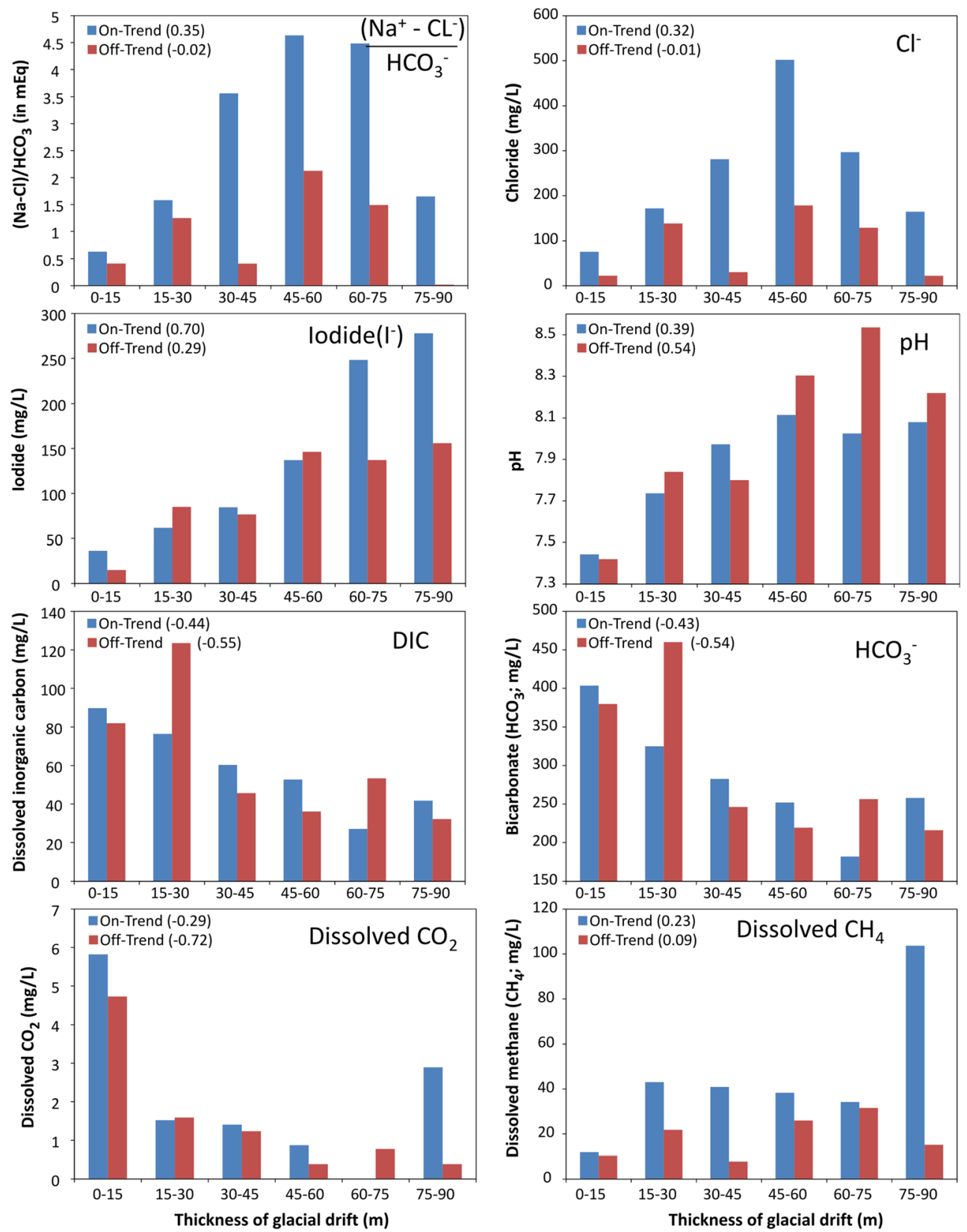

Fig. 12 Concentration averages of parameters for bedrock and interface wells in the Kettle Point Formation and Hamilton Group with increasing thickness of glacial sedimentary cover (i.e. depth to rock). The $\mathrm{pH}$ averages are geometric. Correlation coefficients for on- and off-trend samples are shown in parentheses. On-trend samples fall broadly on the depth- $\delta^{18} \mathrm{O}$ trend (Fig. 5) and are considered to be waters unmodified by recent pumping-related mixing, whereas off-trend samples show a greater degree of mixing than is typical for their depth and may be influenced by pumping-related recharge. The ratio of $(\mathrm{Na}-\mathrm{Cl}): \mathrm{HCO}_{3}$ was calculated using equivalence units and is, in effect, the proportion of $\mathrm{Na}$ in the water that is derived from cation exchange with the shales

The strong correlation between $\mathrm{CH}_{4(\mathrm{ag})}$ in shale and in glacial sediments overlying the shale (Hamilton 2015) indicate a geologically rapid loss of reduced carbon that could not have been sustained since the Paleozoic Era. This supports the theory that the onset of biogenic $\mathrm{CH}_{4}$ production followed removal of shale-hosted brines by glacial meltwater during and after the Pleistocene (McIntosh and Walter 2006). Regional pumping of the aquifer appears to have accelerated the natural post-glacial brine removal and replacement by bicarbonate-dominant waters in shales, thereby enhancing modern biogenic methane production and associated dissolved products.

\section{Conclusions}

The four Devonian shale units that subcrop in southwestern Ontario include the Port Lampton Group, the Kettle Point Formation, the Hamilton Group and the Marcellus 
Formation. They are exposed almost entirely beneath finegrained glacial sediments and host a bedrock/overburden contact aquifer with naturally sluggish groundwater flow that in places retains a Pleistocene isotopic character (Husain et al. 2004). The Pleistocene groundwater zones have shrunk to less than half the size they were in the $1980 \mathrm{~s}$, as shown by increased $\delta^{18} \mathrm{O}$ and $\delta \mathrm{D}$, and the presence of tritium in groundwater. The most significant groundwater isotopic changes occur near the periphery of a zone of isotopically modern water in the center of the peninsula, and in the Ipperwash Trough buried valley, west of London, where groundwater extraction appears to have exceeded replacement. Water level data indicate the isotopic changes have occurred during widespread potentiometric recovery of the previously over-utilized contact aquifer in the western half of the Devonian shale area, and during drawdown and current depletion of the same aquifer in the eastern half of the study area, where widespread pumping continues. Water levels in the central peninsula, where glacial drift is thinner, have not changed significantly. In the Pleistocene areas, groundwater in the clay aquitard above the contact aquifer has a Pleistocene character and, therefore, the replacement of older groundwaters in the shale contact aquifer occurs by vertical recharge through the thinner glacial sediments in the modern zone, followed by lateral transport through the contact aquifer into areas with thicker drift cover. The decline in the potentiometric surface in the contact aquifer in the Ipperwash Trough west of London is severe and may soon render the aquifer non-viable as a domestic water source.

Younger waters spreading throughout the contact aquifer have displaced or mixed with older waters and perturbed a still dominant isotopic trend of $\delta^{18} \mathrm{O}$ decreasing, from -11 to $-16 \%$, by $0.21 \%$ with every meter of increased drift thickness above the contact aquifer. Waters that plot off this trend have different geochemical characteristics that are suggestive of groundwater geochemical processes in the Devonian shales. As the depth interval increases, the amount of $\mathrm{Cl}$ and degree of ion exchange is greater in older waters than younger off-trend waters, suggesting that the younger waters have not fully equilibrated with the host rock. Conversely the geochemical trends in young and old water are much more similar for $\mathrm{pH}$, iodide and dissolved $\mathrm{CH}_{4}$, which increase with depth; and oxidized carbon species $\left(\mathrm{CO}_{2}, \mathrm{HCO}_{3}\right.$ and DIC), which decrease significantly with depth. The consumption of oxidized carbon species and concomitant production of $\mathrm{CH}_{4}$ and rise in $\mathrm{pH}$ are indicative of methanogenesis. The parallel increase in iodide may result from iodine release as marine organic matter is consumed during this process. Negative correlations with tritium in the younger, off-trend waters in a number of these parameters suggest the geochemical processes are contemporary and geologically rapid.

Elevated $\mathrm{CH}_{4}$ also occurs sporadically in the organicrich Dundee Formation carbonates but only where other electron acceptors, principally $\mathrm{SO}_{4}$, are not present. This may partly explain why the Ordovician shale units, comprising the Queenston and Georgian Bay-Blue Mountain formations, have much lower $\mathrm{CH}_{4}$ than the Devonian units, as they also have higher $\mathrm{SO}_{4}$. Lower organic content in the former also contributes to lower $\mathrm{CH}_{4}$ production (McIntosh et al. 2014). $\mathrm{CH}_{4}$ production in the Devonian shales is a natural phenomenon that appears to have been stimulated by past and present groundwater extraction, which provides oxidized carbon and $\mathrm{H}^{+}$ reactants, and removes the $\mathrm{CH}_{4}$ and $\mathrm{OH}^{-}$products, and iodide and other byproducts. Therefore groundwater use and especially over-use has modified the hydrochemistry in the Devonian shale aquifer and will continue to do so. Despite the very abundant gas associated with the on-land half of the Devonian shale exposure in Ontario, the very shallow nature $(<255 \mathrm{~m})$ and wide utilization of the shale as a water supply aquifer may preclude commercial exploitation of the methane resource.

Acknowledgements The authors would like to thank the 24 students who have diligently worked on field data collection for the Ambient Groundwater Program to date and, in particular, Candace Freckelton for helping to supervise them for 5 out of the 7 years the program has been in existence. Fieldwork was carried out and fully funded by the Ontario Geological Survey, as was geochemical analytical work. The Geological Survey of Canada funded and provided stable isotope analysis for waters and isotopic and compositional analysis of gas samples. Aspects of this work were partly the subjects of a number of graduate and undergraduate theses including those of Kathryn Mellor, Edward Matheson, Hanna Burke and Candace Freckelton. Hamilton would like to thank his colleagues Frank Brunton and Derek Armstrong for their insight and many discussions on the Paleozoic geology of southwestern Ontario. McIntosh would like to acknowledge funding from the United States Geological Survey, New York State Energy Research Development Authority, NSF (EAR-0635685) and the American Chemical Society-Petroleum Research Fund (No. 45284-G2).

Open Access This article is distributed under the terms of the Creative Commons Attribution License which permits any use, distribution, and reproduction in any medium, provided the original author(s) and the source are credited.

\section{References}

Aravena R, Wassenaar LI, Barker JF (1995) Distribution and isotopic characterization of methane in a confined aquifer in southern Ontario. Can J Hydrol 173:51-70

Armstrong DK, Carter TR (2006) An updated guide to the subsurface Paleozoic stratigraphy of southern Ontario. Open file report 6191, 214 pp, Ontario Geological Survey, Sudbury, ON

Armstrong DK, Carter TR (2010) The subsurface Paleozoic stratigraphy of southern Ontario. Ont Geol Surv 7:301

Armstrong DK, Dodge JEP (2007) Paleozoic geology of southern Ontario. Miscellaneous Release Data 219, Ontario Geological Survey, Sudbury, ON

Barnett PJ, Henry AP, Cowan WR (1991) Quaternary geology of Ontario, southern sheet. Map 2556, scale 1:1,000,000, Ontario Geological Survey, Sudbury, ON

Brogly PJ, Martini IP, Middleton GV (1998) The Queenston formation: shale-dominated, mixed terrigenous-carbonate deposits of upper Ordovician, semiarid, muddy shores in Ontario, Canada. Can J Earth Sci 35:702-719 
Brunton FR, Dodge JEP (2008) Karst of southern Ontario and Manitoulin Island. Groundwater Resources Study 5, Ontario Geological Survey, Sudbury, ON

Caley JF (1943) Paleozoic geology of the London area, Ontario. Geological Survey of Canada Memoir 237, GSC Canada, Ottawa, $171 \mathrm{pp}$

Canada Climate Normals (2014) http://climate.weather.gc.ca/ climate normals/index e.html. Accessed 15 Dec 2014

Clark I, Fritz P (1997) Environmental isotopes in hydrogeology. CRC, Boca Raton, FL, 327 pp

Clayton RN, Friedman I, Graf DL, Mayeda TK, Meents WF, Shimp NF (1966) The origin of saline formation waters: 1. isotopic composition. J Geophys Res 71(16):3869-3882

Collins AG, Bennett JH, Manuel OK (1971) Iodine and algae in sedimentary rocks associated with iodine-rich brines. Bull Geol Soc Am 82:2607

Desaulniers D, Cherry J, Fritz P (1981) Origin, age and movement of pore water in argillaceous Quaternary deposits at four sites in southwestern Ontario. J Hydrol 50:231-257

Dollar PS (1988) Geochemistry of formation waters, southwestern Ontario, Canada and southern Michigan, U.S.A. PhD Thesis, University of Waterloo, Canada

Dollar PS, Frape SK, McNutt RH (1991) Geochemistry of formation waters, southwestern Ontario, Canada and southern Michigan U.S.A.: implications for origin and evolution. Open file report 5743, Ontario Geological Survey, Sudbury, ON

Drimmie RJ, Frape SK, Thomas RL (1993) Stable isotope signature of meltwater in the sediments of Lake Erie and Lake Ontario. Proceedings of the International Symposium on Isotope Techniques in Studying Past and Current Environmental Changes in the Hydrosphere and the Atmosphere, IAEA-SM329, IAEA, Vienna

Elderfield H, Truesdale VW (1980) On the biophilic nature of iodine in seawater. Earth Planet Sci Lett 50:105-114

Ferry JG (1992) Biochemistry of methanogenesis. Crit Rev Biochem Mol Biol 27(6):473-503

Fitzgerald WD, Mundry M, Storrison DJ (1979) Drift thickness of the Sarnia-Brights groove area, southern Ontario. Preliminary Map P2368, scale 1:50000, Ontario Geological Survey, Sudbury, ON

Freckelton CN (2013) A physical and geochemical characterization of southwestern Ontario's breathing well region. $\mathrm{PhD}$ Thesis, University of Western Ontario, Canada, Electronic thesis and dissertation repository, Paper 1105

Gao C (2011) Buried bedrock valleys and glacial and subglacial meltwater erosion in southern Ontario, Canada. Can J Earth Sci 48:801-818

Gao C, Shirota J, Kelly RI, Brunton FR, van Haaften S (2006) Bedrock topography and overburden thickness mapping, southern Ontario. Miscellaneous Release Data 207, Ontario Geological Survey, Sudbury, ON

Hamblin AP (2006) The "shale gas" concept in Canada: a preliminary inventory of possibilities. Geol Surv Can Open File Rep 5384:103

Hamilton SM (2011) Ambient groundwater geochemistry data for southwestern Ontario, 2007-2010. Miscellaneous Release Data 283, Ontario Geological Survey, Sudbury, ON

Hamilton SM (2015) Ambient groundwater geochemistry data for southern Ontario, 2007-2014; Ontario Geological Survey, Miscellaneous Release Data 283 - Revised. http:// www.geologyontario.mndmf.gov.on.ca/mndmaccess mndm_dir.asp?type=pub\&id=MRD283-REV. Accessed 19 Jan 2015

Hamilton SM, Brauneder K (2008) The ambient groundwater geochemistry project: year 2. In: Summary of fieldwork and other activities. Open file report 6226, 31-1-34-7, Ontario Geological Survey, Sudbury, ON

Hamilton SM, Brauneder K, Mellor KJ (2007) The ambient groundwater geochemistry project: Southwestern Ontario. In: Summary of fieldwork and other activities. Open file report 6213, 23-1-23-5, Ontario Geological Survey, Sudbury, ON
Hamilton SM, Matheson EJ, Freckelton CN Burke HE (2011) Ambient groundwater geochemistry program: the 2011 Aurora-Orillia study area and selected results for the Bruce and Niagara peninsulas. In: Summary of field work and other activities 2011. Open file report 6270, 32-1-3211 , Ontario Geological Survey, Sudbury, ON

Hem JD (1986) The study and interpretation of the chemical characteristics of natural water, 3rd edn. US Geol Surv Water Supply Paper 2254, 263 pp

Hobbs MY, Frape SK, Shouakar-Stash O, Kennell LR (2008) Phase I regional hydrogeochemistry. Deep geological repository supporting technical report. OPG 00216-REP-01300-00006R00, Ontario Power Generation, Toronto, 138 pp

Horita J, Kendall C (2004) Stable isotope analysis of water and aqueous solutions by conventional dual-inlet mass spectrometry. In: de Groot PA (ed) Handbook of stable isotope analytical techniques, vol 1. Elsevier, Amsterdam, pp 1-37

Husain MM (1996) Origin and persistence of Pleistocene and Holocene water in a regional clayey aquitard and underlying aquifer in part of southwestern Ontario. PhD Thesis, University of Waterloo, CA

Husain M, Cherry J, Frape S (2004) The persistence of a large stagnation zone in a developed regional aquifer, southwestern Ontario. Can Geotech J 41:943-958

IAEA/WMO (2006) Global network of isotopes in precipitation. The GNIP DATABASE. Accessible at http://wwwnaweb.iaea.org/napc/ih/IHS resources gnip.html. Accessed 15 Dec 2014

INTERA Eng. Ltd (2011) OPG's deep geologic repository for low and intermediate level waste. Descriptive Geosphere Site Model, NWMO DGR-TR-2011-24, INTERA, Ottawa

Jackson RB, Vengosh A, Darrah TH, Warner NR, Down A, Poreda RJ, Osborn SG, Zhao K, Karr JD (2013) Increased stray gas abundance in a subset of drinking water wells near Marcellus shale gas extraction. PNAS 110(28):11250-11255

Kargbo DM, Wilhelm RG, Campbell DJ (2010) Natural gas plays in the Marcellus shale: challenges and potential opportunities. Environ Sci Technol 44(15):5679-5684

Karrow PF (1973) Bedrock topography in southwestern Ontario: a progress report. Proc Geol Assoc Can 25:67-77

Long DT, Wilson TP, Takacs MJ, Rezabek DH (1988) Stableisotope geochemistry of saline near-surface ground water: eastcentral Michigan basin. Geol Soc Am Bull 100(10):1568-1577

Malcolm SJ, Price NB (1984) The behavior of iodine and bromine in estuarine surface sediments. Mar Chem 15:263-271

Matheson E (2011) Analysis of the anomalous groundwater geochemistry of the Niagara Peninsula, Ontario, Canada. BSc Thesis, Queen's University, Kingston, ON, $171 \mathrm{pp}$

McIntosh JC, Walter LM (2006) Paleowaters in Silurian-Devonian carbonate aquifers: geochemical evolution of groundwater in the Great Lakes region since the Late Pleistocene. Geochim Cosmochim Acta 70:2454-2479

McIntosh JC, Grasby SE, Hamilton SM, Osborne SG (2014) Origin, distribution and hydrogeochemical controls on methane occurrences in shallow aquifers, southwestern Ontario, Canada. Appl Geochem 50(2014):37-52

McNutt RH, Frape SK, Dollar P (1987) A strontium, oxygen and hydrogen isotopic composition of brines, Michigan and Appalachian basins, Ontario and Michigan. Appl Geochem 2(5):495-505

Mellor KJ (2008) Bedrock lithologies effect on bulk groundwater chemistry in southwestern Ontario. BSc Thesis, University of Birmingham, Birmingham, UK, $122 \mathrm{pp}$

MNR (2013) Ontario Ministry of Natural Resources petroleum well data. www.ogsrlibrary.com/data_free_petroleum_ontario. Accessed 15 Dec 2014 (subscription required)

MOE (2013) Ontario Ministry of the Environment well records data 1899-2013. http1s://www.ontario.ca/environment-and-energy/ well-record-data. Accessed 15 Dec 2014

Moisan TA, Dunstan WM, Udomkit A, Wong GTF (1994) The uptake of iodate by marine phytoplankton. J Phycol 30:580-587 Obermajer M, Fowler MG, Goodarzi F, Snowdon LR (1997) Organic petrology and organic geochemistry of Devonian black 
shales in southwestern Ontario, Canada. Org Geochem 26:229 246

Obermajer M, Fowler MG, Snowdon LR (1998) A geochemical characterization and a biomarker re-appraisal of the oil families from southwestern Ontario, Canada. Bull Can Pet Geol 46:350 378

Ontario Ministry of Natural Resources (1984) Water quantity resources of Ontario. MNR-publication 5932, Ontario Ministry of Natural Resources, Toronto, $72 \mathrm{pp}$

Osborn S, Vengosh A, Warner NR, Jackson RB (2011) Methane contamination of drinking water accompanying gas-well drilling and hydraulic fracturing. PNAS 108:8172-8176

Osborn S, McIntosh JC, Hanor J (2012) Iodine-129, 87Sr/86Sr and trace elemental geochemistry of northern Appalachian Basin brines: evidence for basinal-scale fluid migration and clay mineral diagenesis. Am J Sci 312:263-287

Peeters L (2014) A background color scheme for piper plots to spatially visualize hydrochemical patterns. Groundwater 52(1):6
Sanford BV, Thompson FJ, McFall GH (1985) Plate tectonics: a possible controlling mechanism in the development of hydrocarbon traps in southwestern Ontario. Bull Can Petrol Geol 33:52-71

Singer SN, Cheng CK, Scafe MG (2003) The hydrogeology of southern Ontario. Hydrogeology of Ontario Series, Report 1, Ontario Ministry of the Environment, Toronto

Upstill-Goddard RC, Elderfield H (1988) The role of diagenesis in the estuarine budgets of iodine and bromine. Cont Shelf Res 8(4):405-430

Vidic RD, Brantley SL, Vandenbossche JM, Yoxtheimer D, Abad JD (2013) Impact of shale gas development on regional water quality. Science 340(6134). doi:10.1126/science.1235009. Accessed 15 Dec 2014

Weaver TR, Frape SK, Cherry JA (1995) Recent cross-formational fluid flow and mixing in the shallow Michigan Basin. Geol Soc Am Bull 107:697-707

Worden RH (1996) Controls on halogen concentrations in sedimentary formation waters. Mineral Mag 60:259-274 